\title{
Characteristics, distribution and persistence of thin layers over a 48 hour period
}

\author{
M. A. McManus ${ }^{1, *}$, A. L. Alldredge ${ }^{2}$, A. H. Barnard ${ }^{3}$, E. Boss $^{4}$, J. F. Case ${ }^{2}$, T. J. Cowles ${ }^{5}$, \\ P. L. Donaghay ${ }^{6}$, L. B. Eisner ${ }^{5}$, D. J. Gifford ${ }^{6}$, C. F. Greenlaw ${ }^{7}$, C. M. Herren ${ }^{8}$, \\ D. V. Holliday ${ }^{7}$, D. Johnson ${ }^{9}$, S. MacIntyre ${ }^{10}{ }$, D. M. McGehee ${ }^{7}$, T. R. Osborn ${ }^{11}$, \\ M. J. Perry ${ }^{12}$, R. E. Pieper ${ }^{13}$, J. E. B. Rines ${ }^{6}$, D. C. Smith $^{6}$, J. M. Sullivan ${ }^{6}$, \\ M. K. Talbot ${ }^{14}$, M. S. Twardowski ${ }^{15}$, A. Weidemann ${ }^{9}$, J. R. Zaneveld ${ }^{15}$ \\ ${ }^{1}$ Ocean Sciences Department, University of California Santa Cruz, Santa Cruz, California 95064, USA \\ ${ }^{2}$ Biological Sciences, University of California Santa Barbara, Santa Barbara, California 93106, USA \\ ${ }^{3}$ Bigelow Laboratory for Ocean Sciences, 180 McKown Point Road, West Boothbay Harbor, Maine 04575, USA \\ ${ }^{4}$ School of Marine Sciences, 5741 Libby Hall, University of Maine, Orono, Maine 04473, USA \\ ${ }^{5}$ College of Oceanic \& Atmospheric Sciences, Oregon State University, Corvallis, Oregon 97331-5503, USA \\ ${ }^{6}$ Graduate School of Oceanography, University of Rhode Island, South Ferry Road, Narragansett, Rhode Island 02882, USA \\ ${ }^{7}$ BAE Systems, 4669 Murphy Canyon Road, San Diego, California 92123-4333, USA \\ ${ }^{8}$ Monterey Bay Aquarium Research Institute, 700 Sandholt Road, Moss Landing, California 95003, USA \\ ${ }^{9}$ Naval Research Laboratory, Code 7331, Stennis Space Center, Mississippi 39529, USA \\ ${ }^{10}$ Marine Science Institute, University of California Santa Barbara, Santa Barbara, California 93117-6150, USA \\ ${ }^{11}$ The Johns Hopkins University, 3400 N Charles Street, Baltimore, Maryland 21218, USA \\ ${ }^{12}$ Ira C. Darling Marine Center, School of Marine Sciences, University of Maine, Walpole, Maine 04573, USA \\ ${ }^{13}$ Hancock Institute for Marine Science, University of Southern California, Terminal Island, California 90731, USA \\ ${ }^{14}$ University of Washington, 1492 NE Boat Street, Seattle, Washington 98195, USA \\ ${ }^{15}$ Wet Labs Inc., 620 Applegate Street, Philomath, Oregon 97370, USA
}

\begin{abstract}
The biological and physical processes contributing to planktonic thin layer dynamics were examined in a multidisciplinary study conducted in East Sound, Washington, USA between June 10 and June 25, 1998. The temporal and spatial scales characteristic of thin layers were determined using a nested sampling strategy utilizing 4 major types of platforms: (1) an array of 3 moored acoustical instrument packages and 2 moored optical instrument packages that recorded distributions and intensities of thin layers; (2) additional stationary instrumentation deployed outside the array comprised of meteorological stations, wave-tide gauges, and thermistor chains; (3) a research vessel anchored $150 \mathrm{~m}$ outside the western edge of the array; (4) 2 mobile vessels performing basin-wide surveys to define the spatial extent of thin layers and the physical hydrography of the Sound. We observed numerous occurrences of thin layers that contained locally enhanced concentrations of material; many of the layers persisted for intervals of several hours to a few days. More than one persistent thin layer may be present at any one time, and these spatially distinct thin layers often contain distinct plankton assemblages. The results suggest that the species or populations comprising each distinct thin layer have responded to different sets of biological and/or physical processes. The existence and persistence of planktonic thin layers generates extensive biological heterogeneity in the water column and may be important in maintaining species diversity and overall community structure.
\end{abstract}

KEY WORDS: Thin layer · Bioacoustics · Optics · Bioluminescence · Marine snow · Bacterial production · Physical oceanographic processes

\section{INTRODUCTION}

Plankton biologists have long known that organisms are not distributed homogeneously in the water column (e.g. Cushing 1962, Cassie 1963, Wiebe \& Holland 1968).
Distributions vary both horizontally and vertically across a continuum of space and time scales (reviewed by Mullin 1993). An extensive literature addressing horizontal patchiness has resulted from decades of oceanographic research (e.g. Haury et al. 1978, Mackas \& Boyd 
1979, Bjornsen \& Nielsen 1991, Alldredge et al. 2002). Traditional vertical sampling methods, usually performed with bottles mounted on CTD packages deployed at a relatively rapid rate of descent or with nets, tend to either miss or underestimate local maxima in planktonic features at spatial scales less than several meters in the vertical dimension (Donaghay et al. 1992).

As technology evolves to permit observations at both larger and smaller spatial and temporal scales, new phenomena are often observed. Within the last decade, significant advances in optical and acoustical methods have produced new high-resolution descriptions of the in situ distributions of phytoplankton and zooplankton. Recently, quantitative calibrated optical and acoustical instruments, and methods for their deployment, have been developed which can resolve structures within the water column characterized by vertical scales on the order of tens of centimeters. Such structures often exhibit optical, acoustical, physical, biological and chemical signatures that are distinct from the water just above or below the feature (e.g. Hanson \& Donaghay 1998, Cowles et al. 1998, Holliday et al. 1998). These 'thin layers' range in thickness from a few centimeters to a few meters, may extend horizontally for kilometers, and may persist for days. In a previous study 40 to $50 \%$ of thin phytoplankton layers were $<1 \mathrm{~m}$ in thickness, and $80 \%$ of layers were $<2 \mathrm{~m}$ in thickness (Dekshenieks et al. 2001). This indicates a clear separation in scale between thin layers, and the classical deep chlorophyll a maximum (Anderson 1969). Organisms within thin layers are several orders of magnitude more abundant than in the water immediately above or below the layers. Such dense concentrations of living material have the potential to influence many aspects of marine ecology, including feeding success, growth dynamics, reproduction, behavior and predation by higher trophic levels.

Following initial deployments of new instruments and the discovery of these structures, several individual investigators and a few small research groups merged their independent research efforts to study thin layers during the 1998 'Thin Layers Experiment'. This project was a multidisciplinary effort designed to quantify the biological and physical processes contributing to thin layer dynamics. The experiment took place in East Sound, Washington, USA between June 10 and June 25, 1998. This paper describes the changes in characteristics, distribution and persistence of thin layers of zooplankton, marine snow, phytoplankton, bioluminescence and bacterial production over a $48 \mathrm{~h}$ period extending from noon on June 19 to noon on June 21, 1998.

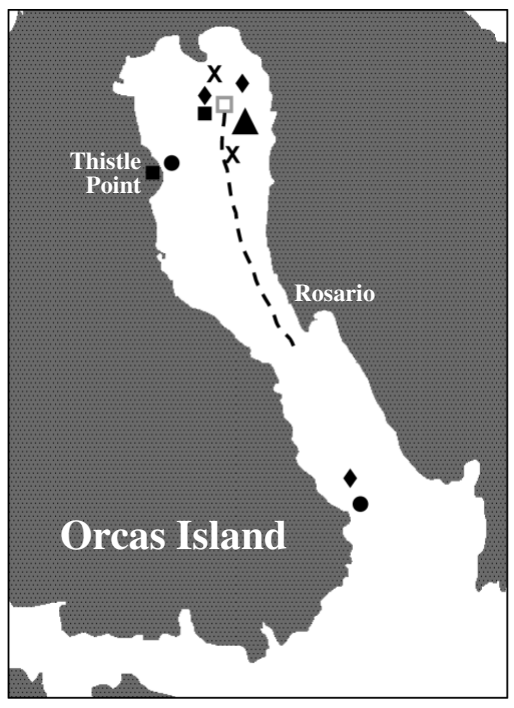

Fig. 1. Locations of Strait of Georgia, Strait of Juan de Fuca and San Juan Islands. Sampling area, East Sound, is enclosed by a rectangle. Inset shows details of sampling area, including location of array $(\boldsymbol{\Delta})$ and instrumentation deployed outside array as follows: meteorological stations ( $\boldsymbol{\square})$, wave and tide gauges $(\bullet)$, and thermistor chains $(\bullet)$. Also shown are moored location of RV 'Henderson' (ㅁ), transect of 'Third Love' (---); and stations of 'Tyee Moon' (X) 


\section{MATERIALS AND METHODS}

Study Area. East Sound is a small fjord located in the US Pacific Northwest near the Canadian border (Fig. 1). It is approximately $13 \mathrm{~km}$ in length, $2 \mathrm{~km}$ in width and $30 \mathrm{~m}$ in depth. There is a partial sill extending across the western side of the lower Sound at a depth of $12 \mathrm{~m}$, while the eastern side of the lower Sound has a depth of $\sim 40 \mathrm{~m}$.

Sampling. The spatial and temporal scales characteristic of thin layers in East Sound were studied using a nested sampling strategy; 4 major types of platforms were utilized. (1) Moored instrument packages formed a triangular array to measure 4 -dimensional (3 spatial and 1 temporal) distributions and intensities of thin layers over a discrete portion of the Sound. (2) Additional stationary instrumentation deployed outside the array was comprised of 2 meteorological stations, 2 wave-tide gauges and 3 thermistor chains. (3) A research vessel, RV 'Henderson', was anchored $150 \mathrm{~m}$ outside the western edge of the array. Researchers on this platform obtained finescale biological and physical data on thin layers. (4) Two mobile vessels, 'Tyee Moon' and 'Third Love', performed basin-wide surveys in order to define the spatial extent of thin layers and the hydrography of the Sound.
Instrumentation deployed in array. We moored 3 Tracor Acoustical Profiling Sensors (TAPS-6, BAE Systems) (A: Fig. 2) in a triangular array. The array, which measured $300 \mathrm{~m}$ on each side, was located $700 \mathrm{~m}$ from shore in $21.5 \mathrm{~m}$ of water. A taut-moored buoy was used to position each TAPS-6 sensor in an upward-facing mode at a depth of $10 \mathrm{~m}$. Each TAPS- 6 sampled at 1 min intervals with a vertical resolution of $12.5 \mathrm{~cm}$. The moorings were connected to a shore station by underwater power-data cables.

We deployed 2 bottom-mounted autonomous underwater winch profilers (ORCAS profilers; Seabird, WetLabs, URI) at 2 corners of the array (B: Fig. 2). A SeaBird SBE-25 CTD on each profiler measured temperature, salinity, pressure, and oxygen. A WET Labs ac-9 on each profiler measured total absorption and attenuation of light at 9 wavelengths between 412 and $715 \mathrm{~nm}$. High-resolution vertical profiles were collected hourly between the bottom and the surface at an average ascent rate of $5 \mathrm{~cm} \mathrm{~s}^{-1}$. Between profiles, the sensor package was held stationary at the bottom until the next sampling interval. Both moorings were connected to a shore station by underwater power-data cables for realtime data collection. This link also provided an opportunity for investigators to manually modify data sampling protocols. We deployed $1 \mathrm{RD}$ Instruments

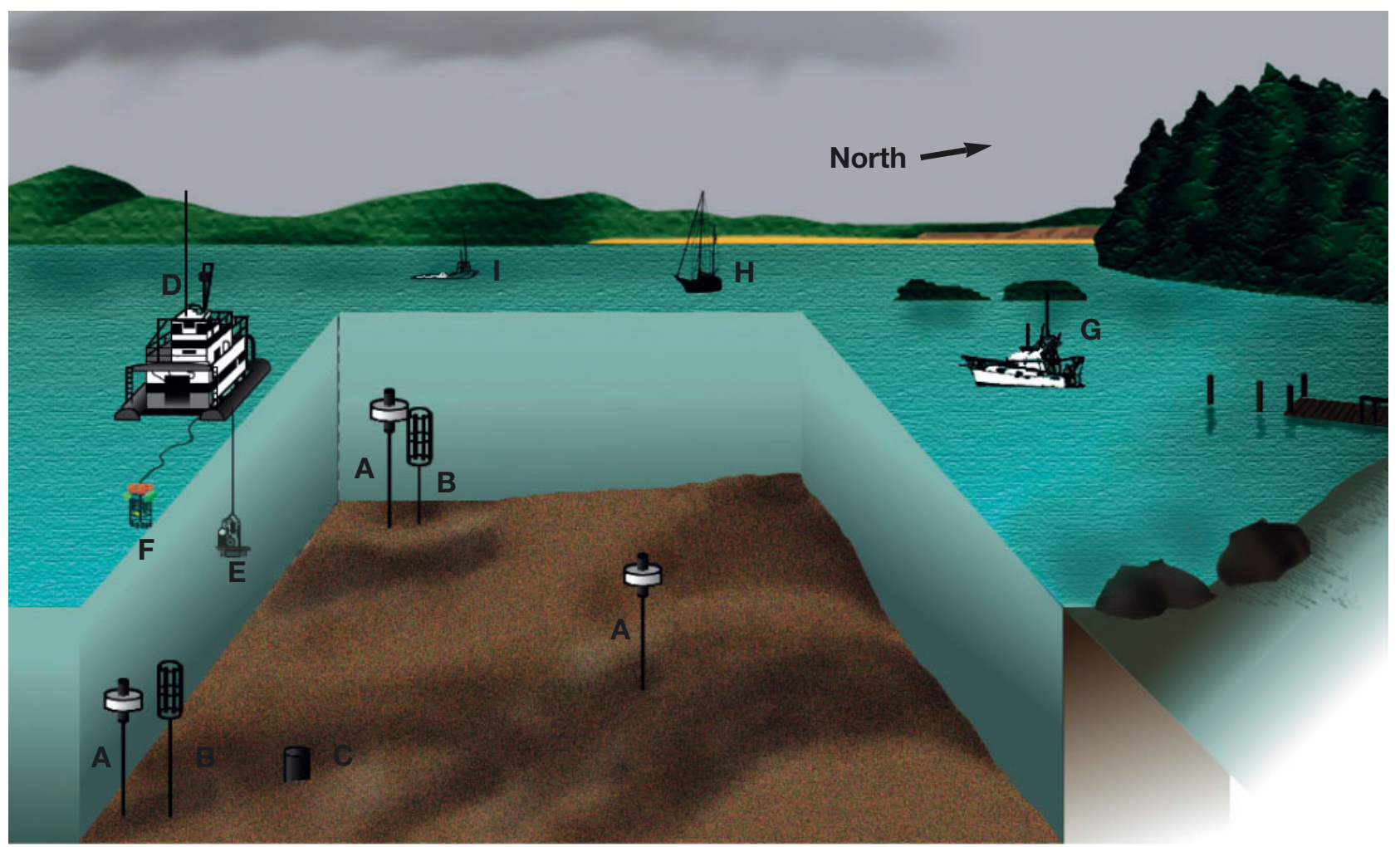

Fig. 2. Instrumentation deployed in array and from RV 'Henderson'. A: Tracor Acoustical Profiling System (TAPS-6); B: autonomous underwater winch profilers (ORCAS); C: $300 \mathrm{kHz}$ acoustic Doppler current profiler (ADCP); D: RV 'Henderson'; E: discrete depth water-sampling package; F: free-falling package; G: 'Tyee Moon'; H: 'Third Love'; I: utility boat 
upward-facing $300 \mathrm{kHz}$ acoustic Doppler current profiler (ADCP) at the southern edge of the array (C: Fig. 2). Profiles of current velocity were collected at $15 \mathrm{~min}$ intervals, with a vertical resolution of $1 \mathrm{~m}$.

Instrumentation deployed outside array. A Davis meteorological station was located on the western side of the upper Sound at Thistle Point (Fig. 1: inset). This site was chosen for its direct line of exposure with the mouth of the Sound. A second meteorological station was located aboard RV 'Henderson' (D: Fig. 2), which was moored on the western side of the array. Both stations logged air temperature, wind speed and wind direction at 20 min intervals. The latter station was also equipped with a camera that recorded sea-surface conditions (e.g. white capping, surface slicks) in the vicinity of the array.

We deployed 2 SeaBird Seagauge ${ }^{\mathrm{TM}}$ wave and tide gauges. One was located on the sill at the mouth of the Sound and a second on the western side of the upper Sound. The latter location was chosen because of its exposure to the waves propagating up the Sound (Fig. 1: inset). These instruments measure temperature, salinity and pressure at 15 min intervals.

A time-series of water temperature was collected using Oregon Environmental Instruments temperature/ pressure loggers (OEI, Model 9311). The self-contained loggers have a $10 \mathrm{~s}$ time constant, an accuracy of $0.01^{\circ} \mathrm{C}$ and a resolution of $0.001^{\circ} \mathrm{C}$; measurements were obtained every $20 \mathrm{~s}$. A total of 3 thermistor chains were deployed, each chain having at least 1 combined temperature/pressure logger. The first thermistor chain was located approximately $100 \mathrm{~m}$ inside the sill at the mouth of the Sound; the second was located near the northern corner of the array; the third was deployed from RV 'Henderson' (Fig. 1: inset). On the chain deployed near the sill, the uppermost logger was located $2.5 \mathrm{~m}$ below the surface. All loggers on this chain were located roughly $2 \mathrm{~m}$ apart. On the chain deployed near the northern corner of the array, the uppermost logger was located at the surface. Additional loggers on this chain were located at roughly $1.5 \mathrm{~m}$ apart. On the chain deployed from RV 'Henderson', loggers were deployed at $1 \mathrm{~m}$ intervals between 1 and $5 \mathrm{~m}$ depth. Isotherm displacements were obtained by linear interpolation between thermistors. True isotherm depths were calculated relative to the surface from OEI pressure data.

Instrumentation and methods employed on RV 'Henderson'. The RV 'Henderson' was positioned in a 2-point mooring on the western side of the triangular array (Fig. 1: inset; D: Fig. 2). It was used as a central support laboratory, serving as a platform for deployment of 4 profiling instrument packages: 3 packages could be deployed simultaneously, 1 from the forward and 2 from the aft portion of the $27 \mathrm{~m}$ vessel, permitting synoptic data collection.
Discrete-depth water-sampling package: Water samples were collected from discrete depths using a profiling CTD/transmissometer package fitted with a siphon (after Donaghay et al. 1992) (E: Fig. 2). Realtime measurements of temperature, salinity (conductivity), transmissometry and $\mathrm{O}_{2}$ were displayed on a shipboard computer. The siphon was primed using a pump prior to sample collection. The profiling package was deployed through the water column manually (descent rate $\sim 2 \mathrm{~cm} \mathrm{~s}^{-1}$ ) to locate thin layers using realtime transmissometry data. Repeat casts were performed over a period of approximately $30 \mathrm{~min}$ to ensure that the layer was persistent. Once a layer was targeted, water samples were collected at discrete depths, an activity made possible by RV 'Henderson's stability while at anchor.

To collect water samples from discrete depths, the profiling/siphon package was lowered sequentially to target depths and maintained at each depth for the duration of collection $\left(\sim 10 \mathrm{~min} \mathrm{depth}^{-1}\right)$. At each collection depth the siphon hose was flushed initially for 4 min to eliminate smearing between samples collected at different depths. Water from each target depth was collected into a 201 polycarbonate carboy using a submerged siphon tube to reduce turbulence in the collecting vessel. The collected water was then transferred from the collecting vessel to various sample bottles by gentle siphoning through silicone tubing. The flow rate of the siphon system was 1 to $21 \mathrm{~min}^{-1}$. Microplankton organisms, including large chain-forming and colonial diatoms, were collected intact and in excellent condition by the siphon system.

A detailed vertical profile was collected on June 20 between 09:00 and 13:00 $\mathrm{h}$ during the flood tide. The vertical structure of the water column was first characterized using the CTD/transmissometer package, and then discrete water samples were collected from the surface to $13.25 \mathrm{~m}$, with a vertical spacing of 0.25 to $1.0 \mathrm{~m}$ between sampling depths. Sample volumes were $100 \mathrm{ml}$ for chlorophyll $a, 250 \mathrm{ml}$ for microplankton, $20 \mathrm{ml}$ for nanoplankton, 21 for determination of particulate absorption, and $500 \mathrm{ml}$ for measurement of bacterial production. Repeat vertical profiles of CTD/ transmissometry were collected mid-way through discrete sample collection and at the end to confirm the layer's location in the water column.

Extracted chlorophyll a was measured by fluorometry (Parsons et al. 1984).

Microplankton (20 to $200 \mu \mathrm{m}$ ) samples were preserved with $10 \%$ (v/v) acid Lugol's solution and $100 \mathrm{ml}$ aliquot samples were processed using an inverted microscope at $200 \times$ magnification (Gifford \& Caron 2000). A replicate set of microplankton samples was preserved in formalin for investigators aboard a second vessel, the 'Tyee Moon'. These samples were pro- 
cessed with the phytoplankton samples from the 'Tyee Moon'.

Nanoplankton (2 to $20 \mu \mathrm{m}$ ) samples (data not presented here) were preserved with $1.5 \%$ cold glutaraldehyde, dual-stained with DAPI and proflavine, collected onto black Nuclepore ${ }^{\mathrm{TM}}$ filters, and later processed using epifluorescence microscopy. The matrix of Chaetoceros socialis colonies (a colonial diatom that comprised a majority of the thin phytoplankton layers observed in this study) was not preserved in acid Lugol's fixative, but was preserved intact on the filters prepared for epifluorescence, permitting enumeration of both the total number of $C$. socialis cells and colonies. C. socialis cells and colonies were enumerated at $200 \times$ magnification using a compound microscope equipped for epifluorescence.

Particulate absorption was determined using the quantitative filter-pad method (Mitchell \& Kiefer 1988, Bricaud \& Stramski 1990). Three $500 \mathrm{ml}$ replicate aliquots were passed through the same $274 \mu \mathrm{m}$ Nitex prefilter to minimize uneven cell distribution on the filter caused by the Chaetoceros socialis colonies. Each replicate was filtered onto individual GF/F glass-fiber filters. The Nitex prefilter was back-washed with filtered seawater to resuspend cells $>274 \mu \mathrm{m}$, and these cells were then collected onto a single GF/F filter. The 4 filters were frozen in liquid nitrogen for later analysis by spectrometry. Absorption at $750 \mathrm{~nm}$ was used as a zero baseline. Detrital absorption $\left(a_{\mathrm{det}}\right)$ was obtained by the Kishino methanol extraction method (Kishino et al. 1985). Phytoplankton absorption $\left(a_{\mathrm{p}}\right)$ was then calculated as the difference between particulate absorption and detrital absorption $\left(a_{\mathrm{p}}-a_{\mathrm{det}}\right)$.

Bacterial production was measured by the method of ${ }^{3} \mathrm{H}$-leucine incorporation (Kirchman et al. 1985), modified for microcentrifugation (Smith \& Azam 1992). Triplicate $1 \mathrm{ml}$ aliquots were incubated with $20 \mathrm{nM}$ (final concentration) ${ }^{3} \mathrm{H}$-leucine at in situ temperature. Leucine incorporation was converted to carbon units according to the method of Simon \& Azam (1989). During the study period, bacterial production assays were performed on samples collected from 4 vertical profiles: 1 profile of bacterial production was collected with the discrete-depth water-sampling package (30 depths profile ${ }^{-1}$ ), and 3 profiles were collected with the free-falling package described in the following subsection (12 depths profile ${ }^{-1}$ ).

Free-falling package: Rapidly repeated profiles $\left(\sim 10 \mathrm{~h}^{-1}\right)$ of the water column with a free-falling instrument package (F, Fig. 2) provided the time-series necessary to define the temporal patterns of persistence of micro- and fine-scale vertical structure of hydrography, bio-optical properties, the vertical gradient in horizontal velocity, and turbulent kinetic energy dissipation. The free-fall package consisted of a Sea Bird 911+
CTD with $\mathrm{O}_{2}$ sensor, 2 multi-wavelength absorption and attenuation meters (ac-9), a multi-wavelength excitation/emission fluorometer (SaFIRE, WET Labs), and a conventional single wavelength fluorometer (WetStar, WET Labs). The instrument package also carried an acoustic Doppler velocimeter (ADV) (Ocean Probe, Sontek), to measure current velocities. The vertical resolution of the ADV is 0.20 to $0.25 \mathrm{~m}$. In addition, temperature-gradient microstructure was measured with a self-contained autonomous microstructure profiler (SCAMP, RME) attached to the free-fall system. The SCAMP microstructure measurements permitted estimation of turbulent kinetic energy dissipation and mixing (MacIntyre et al. 1999). The buoyancy of the package was adjusted to provide a free-fall descent rate of 10 to $12 \mathrm{~cm} \mathrm{~s}^{-1}$, thus resolving physical and bio-optical properties over vertical scales of a few centimeters for all the instruments (Cowles et al. 1998) except the SCAMP which, as it samples at $100 \mathrm{~Hz}$, resolves over scales of a few millimeters.

The free-fall instrument package was equipped with a Sea Bird 32 rosette sampling system with twelve $500 \mathrm{ml}$ sampling bottles. Real-time display of hydrographic and bio-optical properties permitted identification of persistent finescale features (thin layers) in the water column, and discrete samples were collected in and around these features with the rosette sampling system during free-fall profiling. Following discrete sample collection, the profiling system was returned to the deck, and discrete samples for chlorophyll and nutrient analysis were drawn from the sampling bottles.

Acoustics package: A profiling package outfitted with an 8-frequency Tracor Acoustical Profiling System (TAPS-8), a SeaBird $911^{+}$CTD, an irradiance sensor and a newly developed bathyphotometer (J. F. Case, C. M. Herren, C. L. Johnson, S. H. D. Haddock unpubl. data) was used to collect detailed vertical profile data in response to real-time displays of acoustical profiles from each of the 3 moored TAPS- 6 sensors in the array. A high-volume pump for collecting small zooplankton was also utilized in conjunction with the acoustics package.

Bioluminescence profiles were collected hourly from dusk to dawn between June 20 and 21 with a bathyphotometer mounted on the acoustics package. The profiling bathyphotometer mechanically stimulated bioluminescence to occur via an impeller pump. The resulting bioluminescence was then detected by a photomultiplier tube inside the light-baffled detection chamber of the instrument. Profiles were recorded and observed in real time from RV 'Henderson', and plankton samples were collected at discrete depths with reference to the bioluminescence profiles. A vertically profiling image-intensified video-camera (Mini-SplatCam), modified from the original concept by $\mathrm{E}$. Widder 
(Widder et al. 1989, 1992), was also deployed from RV 'Henderson' to study the distribution of larger bioluminescent organisms, such as gelatinous and crustacean zooplankton.

Marine snow camera package: Vertical profiles of the abundance and size distributions of marine snow aggregates $>0.5 \mathrm{~mm}$ in diameter were obtained over the study period by photographing undisturbed particles in situ in a collimated slab of light. The system consisted of a Photosea $50035 \mathrm{~mm}$ still camera synchronized with a Photosea 550S strobe and a SeaBird $911^{+}$CTD for depth calibration with the other instrument packages. Each camera profile produced 180 to 200 photographs, with no overlap of imaged fields and a depth accuracy of $10 \mathrm{~cm}$. A frame size of $35 \times 25 \times$ $5 \mathrm{~cm}$ (4.4 l) was photographed for each image. Images were recorded on T-max 400 ASA black-and-white film (800 exposure rolls). All aggregates $>0.065 \mathrm{~mm}^{3}$ equivalent spherical volume (ESV: $0.5 \mathrm{~mm}$ diameter) contained in the photographs were counted and sized using computerized image-analysis (MacIntyre et al. 1995). Vertical profiles of cumulative aggregate volume, mean aggregate size and total aggregate numbers $\mathrm{l}^{-1}$ were constructed from each profile.

Instrumentation and methods employed on 'Tyee Moon'. The 'Tyee Moon', a 10 m motor vessel (G: Fig. 2), was equipped with an RD Instruments downwardfacing $1200 \mathrm{kHz} \mathrm{ADCP}$ and a high-resolution profiling package. The $1200 \mathrm{kHz}$ ADCP, attached to the side of the vessel, measured current magnitude and direction at a $50 \mathrm{~cm}$ vertical resolution. The high-resolution profiling package consisted of a SeaBird $911^{+}$CTD with oxygen and pH probes, a WET Labs WET Star chlorophyll fluorometer, and 2 ac-9s. These ac-9s were used to measure total, dissolved and particulate absorption and attenuation (Twardowski et al. 1999). Water samples for analysis of large phytoplankton were collected from discrete depths using a siphon system. Surface samples were collected with a bucket. Subsamples of water collected from each target depth were examined live using phase-contrast microscopy, and videotaped for archival purposes. Whole water was preserved with $4 \%$ formalin buffered with $\mathrm{NaOH}$. Samples were concentrated on a $20 \mu \mathrm{m}$ mesh, and later processed in a Sedgwick-Rafter chamber using a compound microscope at $200 \times$ magnification.

Across-Sound and along-Sound transects of physical and optical data were collected from June 10 to 25. In order to determine whether the taxonomic composition of an optically detected phytoplankton layer was consistent over its horizontal extent, bulk-water samples were collected at locations north and south of the RV 'Henderson' on June 19 by investigators on the 'Tyee Moon'. First, an ac-9 was used to determine layer depth. Discrete water samples were then siphoned from above, within and below the layer, and processed as described previously.

Instrumentation and methods employed on "Third Love'. A SLOW Descent Rate Optical Package (SLOWDROP) (Barnard et al. 1998) was used to sample physical (SeaBird SBE-25) and inherent optical properties (ac-9). The package was lowered from the aft boom of a $13 \mathrm{~m}$ twin-masted sailboat, the 'Third Love' (H: Fig. 2). Sampling was done in a tow-yo mode, with the package remaining in the water between profiles. A spatial transect was performed on June 18 from 08:12 to 12:35 $\mathrm{h}$ while the vessel drifted up the Sound with the wind from the middle of East Sound (Rosario Point) to the northern region of the Sound (RV 'Henderson') (Fig. 1: inset). Information from the 'Third Love' instrument package is used to describe physical and optical properties of the Sound prior to the $48 \mathrm{~h}$ study period.

\section{RESULTS}

\section{Physical forcing}

In order to understand the spatial distribution and temporal occurrence of thin layers, it is necessary to understand local and regional physical forcing. Wind and tidal forcing are the primary influences on circulation patterns in East Sound. The surface layer (2 to $12 \mathrm{~m}$ ) flows in the direction of the wind. Deeper flows are tidally driven, and there is often a strong density $\left(\sigma_{t}\right)$ interface between the wind-forced surface layer and the tidally-influenced layer below it (Dekshenieks et al. 2001). The water masses in East Sound also vary temporally due to mixing of higher $\sigma_{\mathrm{t}}$ water from the Strait of Juan de Fuca with lower $\sigma_{\mathrm{t}}$ water from the Strait of Georgia. The Strait of Georgia is heavily influenced by the Fraser River, which supplies over $80 \%$ of the total annual freshwater to both Straits (Thomson 1981). The rivers' maximum outflow occurs in May and June. Previous studies have shown that pulses of lower $\sigma_{t}$ water are episodically advected from the Strait of Georgia into the Strait of Juan de Fuca (Redfield 1950). These events occur near neap tide when tidal mixing in the channels surrounding the San Juan Islands is at a minimum. Further, when winds are from the north, coincident with the neap tide, the volume of lower $\sigma_{t}$ water advected through the channels is enhanced significantly (Griffin \& LeBlond 1990, Hickey et al. 1991).

Between June 10 and June 12, 1998, a sustained north wind event combined with a neap tide produced the appropriate conditions for lower $\sigma_{t}$ water from the Strait of Georgia to be advected toward East Sound. Between June 13 and 15, the lower $\sigma_{t}$ water moved into the Sound at the surface, rapidly displacing the pycno- 
cline to an average depth of $17 \mathrm{~m}$. The lower $\sigma_{\mathrm{t}}$ water mass was a region of intense vertical mixing with a calculated Richardson number (Ri) $<0.25$. Thus, between June 13 and 15, the only stable region of the water column (Ri > 0.25) was located below $17 \mathrm{~m}$, a depth with a light level of $<1 \%$. After several days of southerly winds, higher $\sigma_{\mathrm{t}}$ waters from the Strait of Juan de Fuca were eventually advected into the Sound, resulting in a gradual shoaling and strengthening of the pycnocline between June 18 and 21.

Spatial and temporal measurements of $\sigma_{t}$ and chlorophyll made from the 'Third Love', on June 18 show a spatially coherent concentration of chlorophyll extending from the middle of East Sound (Rosario Point) to the northern region of the Sound (the RV 'Henderson'). At Rosario Point, the feature formed a broad layer between the surface and $8 \mathrm{~m}$, while to the north it was a thin $1 \mathrm{~m}$ sub-surface layer located at $12 \mathrm{~m}$ (Fig. 3). During June 18, this chlorophyll layer was observed to

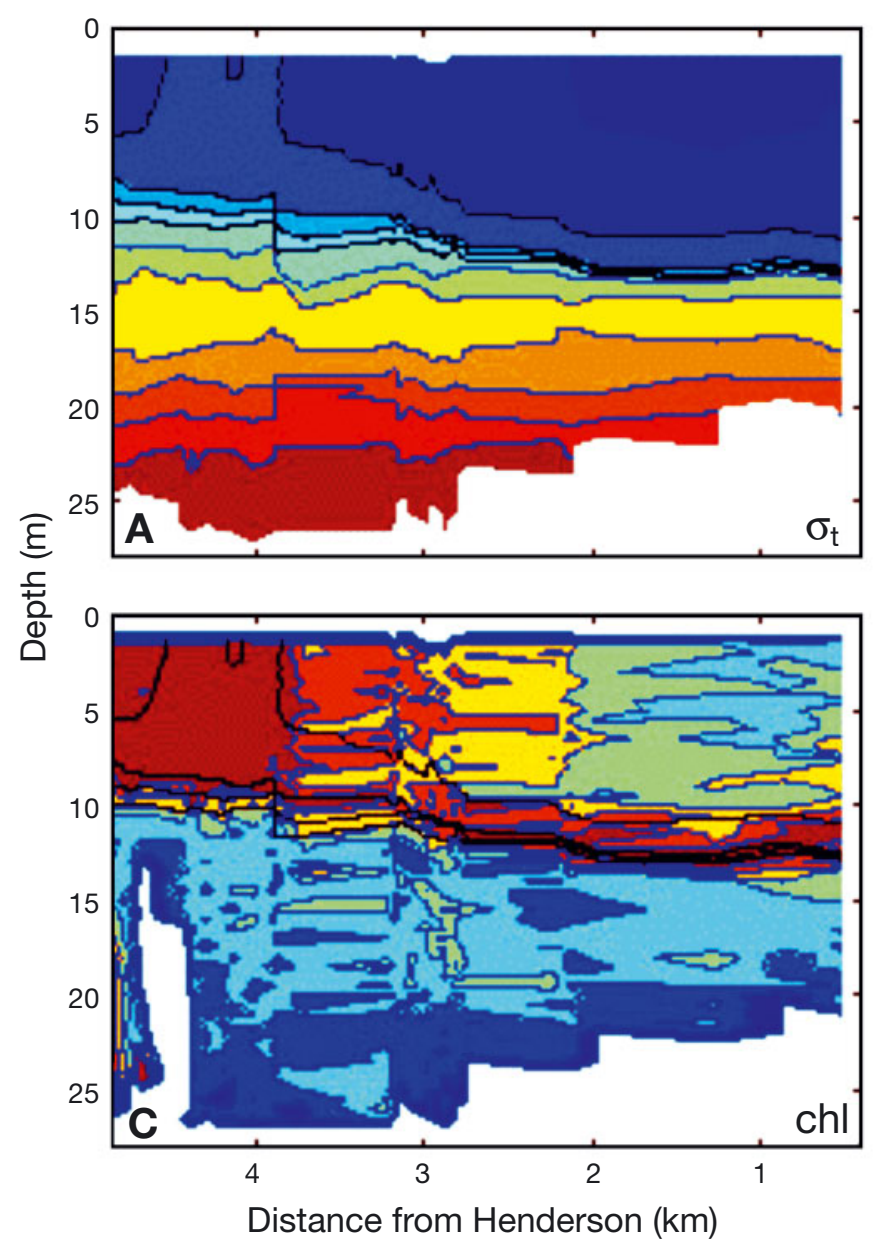

thin, and to rise by roughly $2 \mathrm{~m}$ in depth at the RV 'Henderson', as the higher $\sigma_{\mathrm{t}}$ water mass was advected along the bottom into the northern region of the Sound. It is important to note that layer depth followed the isopycnal distribution. The thin layer in the northern region of the Sound persisted for the following $3 \mathrm{~d}$ (June 19 to 21) a point central to the discussion that follows.

\section{June 19-June 21}

\section{Changes in hydrography}

Following several days of southerly winds, higher $\sigma_{\mathrm{t}}$ water from the Strait of Juan de Fuca was advected into the Sound below the lower $\sigma_{t}$ surface layer. The result was a gradual shoaling and strengthening of the pycnocline (Fig. 4A). In this study, the pycnocline
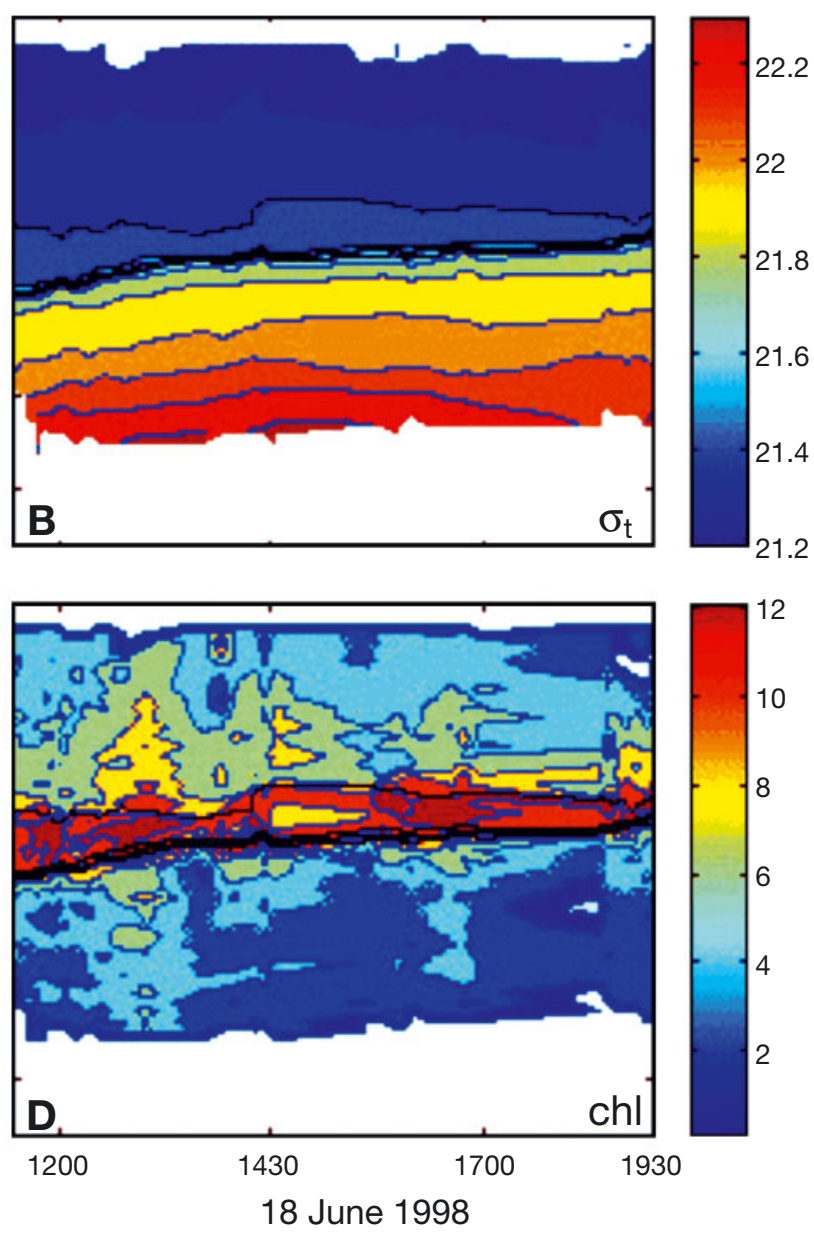

Fig. 3. (A) $\sigma_{t}$ along transect from Rosario Point to RV 'Henderson'. (B) Time-series of $\sigma_{t}$ measured from RV 'Henderson'. $\sigma_{t}$ contours $(21.4,21.5,21.6,21.7)$ are drawn in black in (A) and (B). (C) Chlorophyll concentration ( $\mu \mathrm{g} \mathrm{l}^{-1}$ ) along transect from Rosario to RV 'Henderson'. (D) Chlorophyll concentration $\left(\mu \mathrm{g}^{-1}\right)$ at RV 'Henderson'. Chlorophyll concentration estimated from $\left(a_{\mathrm{p}} 676-a_{\mathrm{p}} 650\right) / 0.012$ (where $a_{\mathrm{p}}=$ phytoplankton absorption); red $=$ chlorophyll concentrations $>12 \mu \mathrm{g} \mathrm{l}^{-1}$. 'Third Love' was next to RV 'Henderson' at approximately $14: 30 \mathrm{~h}$ on June 18 ; non-plotted values at bottom of graphs are due to sediments for which $a_{\mathrm{p}} 676-a_{\mathrm{p}} 650<0$ 
ranged from 21.30 to $21.88 \sigma_{\mathrm{t}}$. Over this $48 \mathrm{~h}$ period, 2 distinct regions of high shear $\left(>0.06 \mathrm{~s}^{-1}\right.$ ) (calculated after Itsweire et al. 1989) occurred, the first between 12:30 and 22:00 $\mathrm{h}$ on June 19, the second between 12:00 and 22:00 h on June 20. Both regions of high shear were located just above the pycnocline, with an average thickness of 1 to $2 \mathrm{~m}$. Each persisted for $\sim 8 \mathrm{~h}$ (Fig. 4A).

The regions of highest Richardson number (Ri) were located in the pycnocline (Fig. 4B). This is significant, since our 1996 studies in East Sound demonstrated that most thin layers of phytoplankton are found in regions where $\mathrm{Ri}$ is $>0.25$ (Dekshenieks et al. 2001). When Ri is $>0.25$, the water column is stable to shear-instability (Turner 1973) and therefore able to support thin layer development.

Estimates of rates of turbulent kinetic energy dissipation indicated that much of the water column in East Sound was moderately to weakly turbulent where thin layers were observed (Fig. 4C). Dissipation rates $(\varepsilon)$ were highest $\left(\varepsilon>10^{-7} \mathrm{~m}^{2} \mathrm{~s}^{-3}\right)$ in the upper part of the water column, and where shear was greatest. Dissipation rates were low within the pycnocline. These measured values of dissipation support the results obtained from calculation of the Richardson number: turbulence is low where thin layers are observed. Even when dissipation rates increased in the pycnocline, overall values tended to be moderate $\left(<10^{-7} \mathrm{~m}^{2} \mathrm{~s}^{-3}\right)$. Recent evidence has shown that the water column can be turbulent but not support vertical fluxes (Itsweire et al. 1993, Etemad-Shahidi \& Imberger 2001, 2002, Saggio \& Imberger 2001). In general, $\varepsilon$ must exceed $15 v \mathrm{~N}^{2}$ (where $v=$ kinematic viscosity and $\mathrm{N}^{2}=$ buoyancy frequency) for vertical transport to occur (Ivey \& Imberger 1991), and $\varepsilon>100 v \mathrm{~N}^{2}$ for the turbulence to be isotropic (Itsweire et al. 1993). To further describe the turbulent environment, we determined whether the turbulence was (1) isotropic $\left(\varepsilon>100 v^{2}\right)$, (2) sufficient to cause minimal vertical transport $\left(15 v \mathrm{~N}^{2}<\varepsilon<100 v \mathrm{~N}^{2}\right)$, or (3) not likely to support vertical transport $\left(\varepsilon<15 v \mathrm{~N}^{2}\right.$ ) (Fig. 4D). In East Sound, layers were found where the turbulence was insufficient to cause vertical transport; in addition, events that were energetic enough to dis- perse layers (for example solitons) occurred infrequently. Basically, turbulent length scales depend upon the strain ratio $\left(\varepsilon v^{-1} \mathrm{~N}^{-2}\right)^{1 / 2}$ (Saggio \& Imberger 2001). When turbulence occurs at Richardson numbers above 0.25 and at values of $\varepsilon<36 v \mathrm{~N}^{2}$, turbulent length scales tend to be on scales of a few centimeters or less and vertical transport is limited. As the strain ratio increases, overturns become larger (scale on the order of tens of centimeters). Saggio \& Imberger (2001) found that buoyancy flux is 1 order of magnitude lower at low strain ratios relative to its maximum near $\mathrm{Ri} \sim 0.25$ (Saggio \& Imberger 2001). More recent work in a stratified estuary has indicated low buoyancy fluxes even at higher strain rates. Hence, while the water column can be turbulent and induce aggregation (MacIntyre 1998), vertical fluxes are often insufficient to disperse layers. A similar mechanism explained the persistence of a thin layer of elevated $\mathrm{NH}_{4}$ concentrations in Mono Lake, California, over a 4 d period (MacIntyre \& Jellison 2001).

\section{Mesozooplankton}

Acoustical scattering above the TAPS moored in mid-water at the northernmost station in the triangular array of sensors was used to estimate zooplankton displacement volumes in $12.5 \mathrm{~cm}$ vertical bins $\mathrm{min}^{-1}$ during the $2 \mathrm{~d}$ period of intense sampling (Holliday 1977, Holliday et al. 2003). Biovolumes were computed for 2 shapes that approximate the scattering from copepods and mysids. The truncated fluid-sphere model (Pieper \& Holliday 1984) was used to model the scattering from small copepods and a distorted wave Born approximation (DWBA) solution was used to model scattering from elongate scatterers (McGehee et al. 1998). A mysid was used as the basis for the elongate scatterer shapes.

A thin scattering layer was observed just above $10 \mathrm{~m}$ depth on the evening of June 19. The layer ascended slowly through the evening and the next day until about 13:00 h on June 20, when it reached a depth of

Fig. 4. Biological and physical measurements in East Sound between noon June 19 and noon June 21, 1998 (A) Hourly profiles of $\sigma_{\mathrm{t}}$ from ORCAS profiler; contours of velocity shear are superimposed on profiles of $\sigma_{\mathrm{t}}$. (B) Richardson number (Ri); contours of $\sigma_{\mathrm{t}}$ superimposed on Richardson values. (C) Rates of turbulent kinetic energy dissipation $(\varepsilon)$ with $21.4,21.6,21.8$, and 22.0 $\sigma_{t}$ isopycnals overlaid. (D) Time-series of $\varepsilon v^{-1} \mathrm{~N}^{-2}$ with contours as in (C) indicating occurrence of thin layers at depths where vertical transport is suppressed. (E) Total small zooplankton biovolume $\left(\mathrm{mm}^{3} \mathrm{~m}^{-3}\right)$ in water column over northernmost Tracor Acoustical Profiling System (TAPS) mooring as a function of time and depth; biovolume is acoustically measured analog of conventional displacement volume often used when direct sampling of mesozooplankton is done with nets or pumps (a-g). (F) Vertical distribution of marine snow; percentage of total integrated volume of marine snow (aggregates $>0.5 \mathrm{~mm}$ diam.) in water column in $1 \mathrm{~m}$ depth-bins. Density contours in gray; short lines intersecting $y$-axes inside graph denote depth of marine snow maximum at time profile was measured. (G) Chlorophyll (chl) derived from ac-9 measurements, where $\mu \mathrm{g}$ chl $=\left(a_{\mathrm{pg}} 676-0.33 \times\left[a_{\mathrm{pg}} 650-\right.\right.$ $\left.a_{\text {pg }} 715\right]$ ) / 0.017; isopycnals overlie the chlorophyll data, blank area = no data. $(\mathrm{H})$ Vertical distribution of stimulable biolumines-

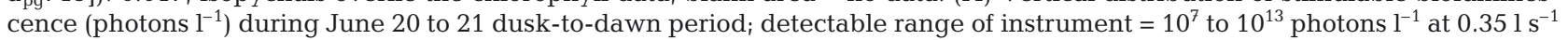
flow rate. Contours of $\sigma_{\mathrm{t}}$ are in gray; $*$ : major layer of bioluminescence 

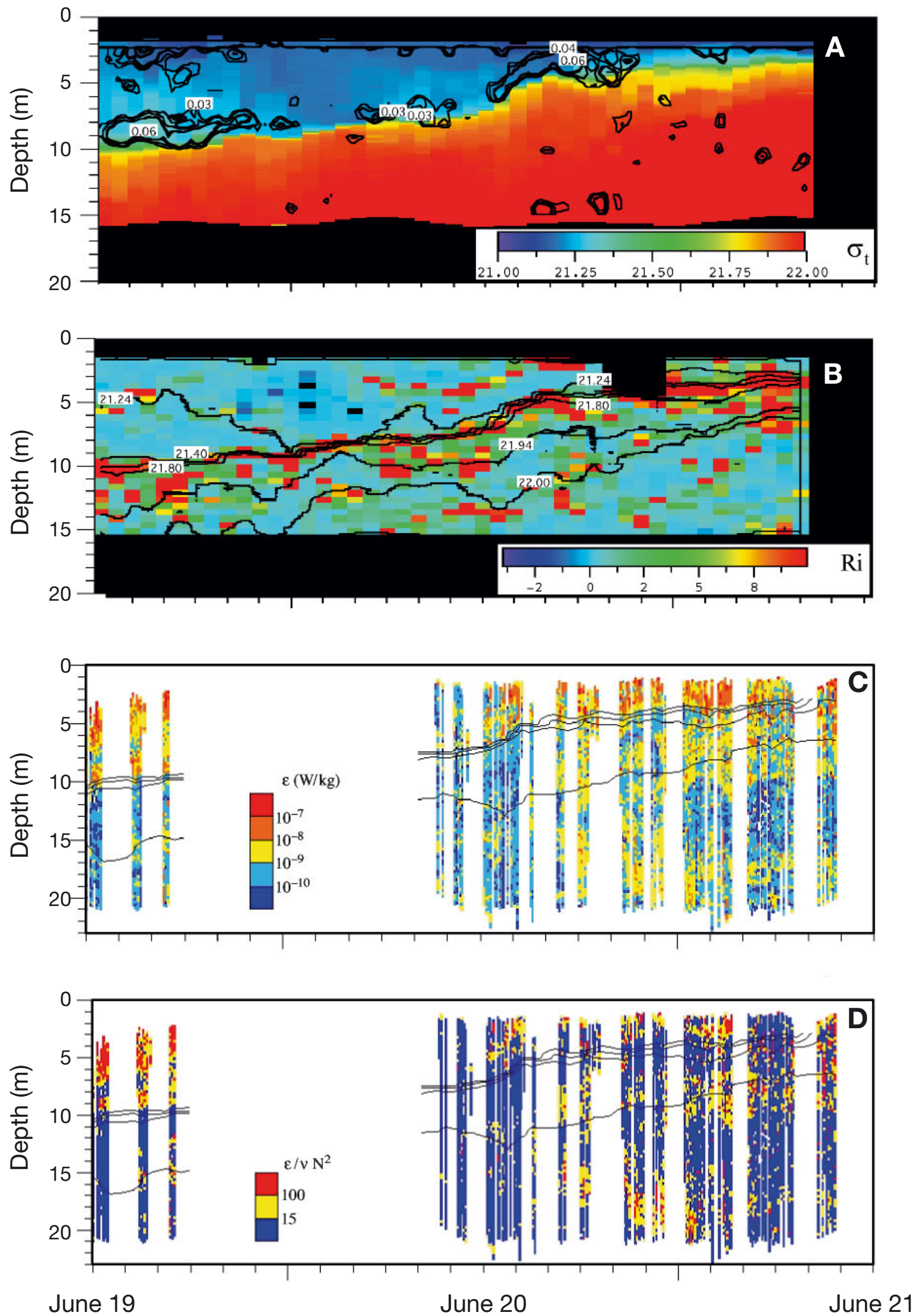

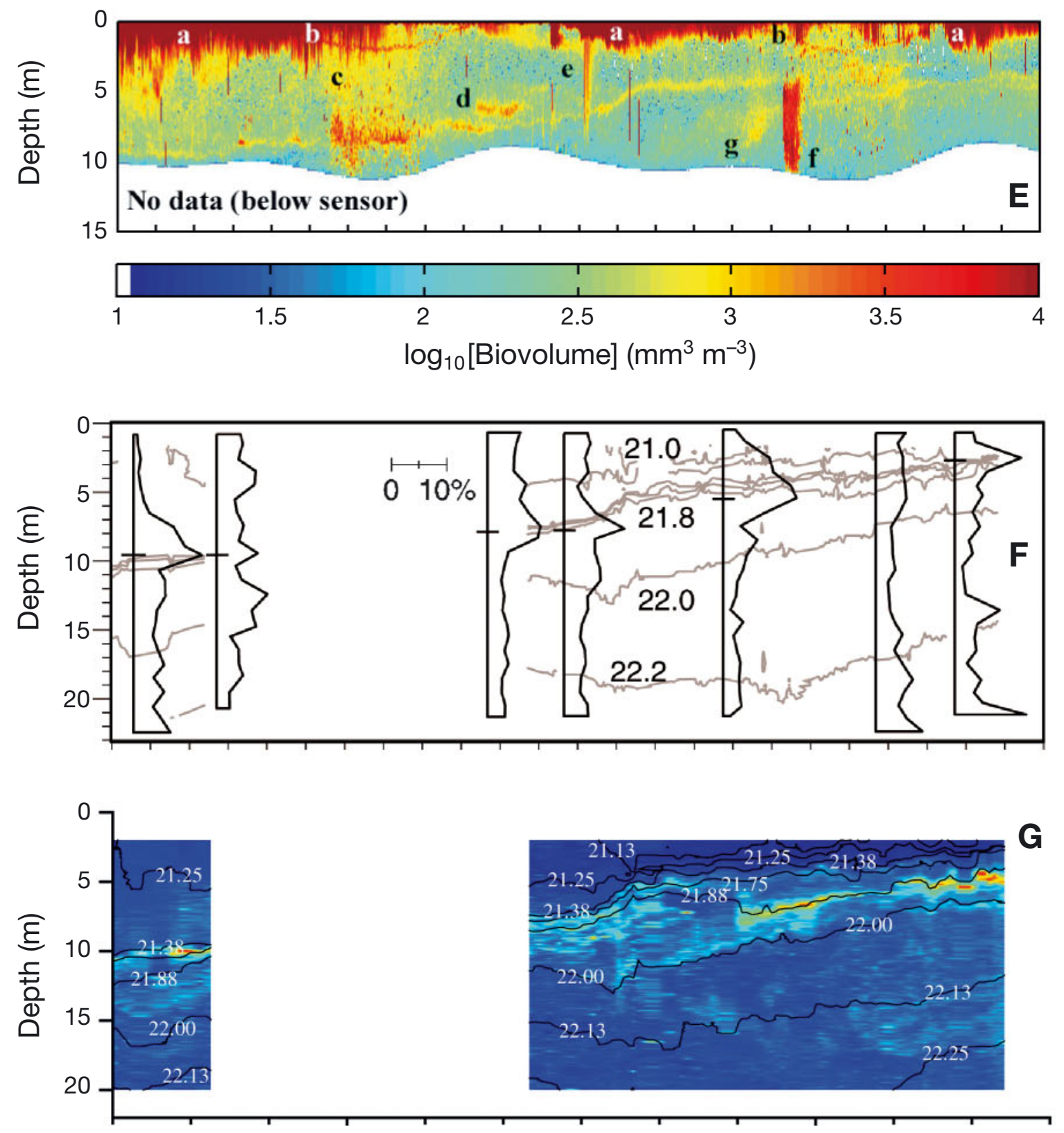

Chlorophyll

$\left(\mu \mathrm{g} \mathrm{I}^{-1}\right)$
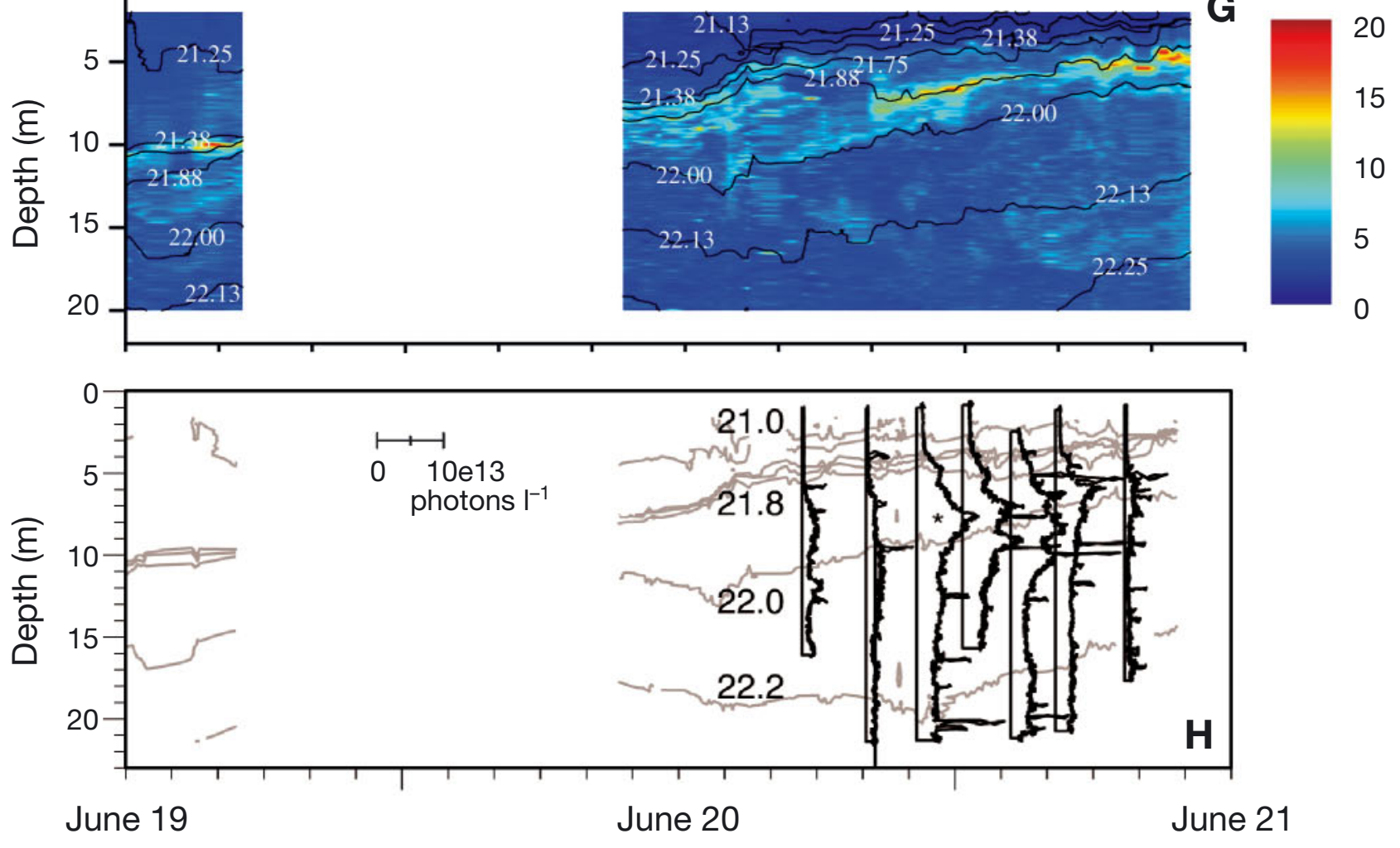

Fig. 4 (continued) 
$6.5 \mathrm{~m}$. The layer then shoaled rapidly, reaching a depth of $4.5 \mathrm{~m}$ at 15:00 $\mathrm{h}$. This layer persisted beyond the time interval shown in Fig. 4E, disappearing into the plumes of high surface scattering during the afternoon of June 21.

High levels of surface scattering (Fig. 4E-a) were correlated with wind speeds at the site. Maximum wind speeds $\left(\sim 6 \mathrm{~m} \mathrm{~s}^{-1}\right)$ and wave heights of only $\sim 10$ to $30 \mathrm{~cm}$ peak-to-peak near the array only rarely produced a breaking wave with subsequent shallow entrainment of air bubbles. Coherent linear patterns of suppressed capillary waves that may have been associated with Langmuir cells were recorded by a camera on the RV 'Henderson' and were also visually monitored during daylight and moonlight hours as they moved slowly across the sensor array. Although the echoes from these high scattering level plumes were often saturated in the TAPS receivers, examination of the unsaturated signals from the lower edges of these plumes revealed acoustic scattering levels and spectra, which might be expected if the scattering were dominated by small bubbles. An $\mathrm{O}_{2}$ sensor on the ORCAS profiler revealed that the upper mixed layer was supersaturated ( 120\% of normal surface values). During a typical daytime ORCAS profile in this period, an $\mathrm{O}_{2}$ minimum $\left(3.8 \mathrm{ml} \mathrm{l}^{-1}\right)$ was found at the depth of the thin zooplankton scattering layer and oxygen values peaked $\left(7.2 \mathrm{ml} \mathrm{l}^{-1}\right)$ at the depth of the optically detected phytoplankton layer (located just below the zooplankton scattering layer). $\mathrm{O}_{2}$ values below the colocated thermocline/oxycline were well below surface saturation values. These plumes of high acoustic scattering cannot be explained by wind-driven injection of bubbles from breaking waves. Their coincidence with Langmuir patterns, along with the high $\mathrm{O}_{2}$ values in the upper water column, suggest a biological source of small bubbles whose formation and retention in the water column is possibly mediated by local surface heating, attachment to phytoplankton, marine snow or detritus which prevents them from rising quickly to the surface, and injection to depths of a few meters by the downward transport associated with one edge of a Langmuir cell.

In Fig. 4E-b, 2 thin traces of high scattering near the surface are artifacts caused by echoes from part of an ORCAS profiler mooring located near the TAPS mooring.

In the upper mixed layer, zooplankton biovolumes increased at dusk each day (e.g. Fig. 4E-c) and decreased again at dawn. Within about $1 \mathrm{~m}$ of the depth of the thin layer on June 19, the total biovolume increased by $\sim 86 \%$ during the hours of darkness (i.e. from about 23:30 to 04:00 $\mathrm{h}$ at this latitude and season). In the thin zooplankton layer, the biomass of organisms with shapes similar to copepods $(<1 \mathrm{~cm}$ total length) increased by $\sim 26 \%$, and that of larger organisms with copepod-like shapes and elongate scatterers increased by 81 and $93 \%$, respectively. Peaks in the distribution of organisms with shapes similar to copepods occurred at total lengths of $<0.45 \mathrm{~mm}(36.9 \%), 2.3 \mathrm{~mm}(32.7 \%)$, $4.1 \mathrm{~mm}(13.5 \%)$, and $5.7 \mathrm{~mm}(17.0 \%)$. The percentages are the fraction of the total biovolume for organisms with shapes similar to copepods, at the indicated sizes. While 4 distinct sizes of elongate scatterers were present, after dusk $61 \%$ of these scatterers were between 15 and $19 \mathrm{~mm}$ total length.

Vertically migrating mysids, such as Neomysis kadiakensis, are good candidates for explaining the increases in the biomass of elongate scatterers on and near the thin layer in this instance (Kringel et al. in press). Mysids were observed with a camera deployed from the RV 'Henderson' at its mooring site adjacent to the TAPS sensor array. The copepods Pseudocalanus spp. also occurred in the evening net tows. These species are known reverse vertical migrators and are native to the northern Puget Sound area (Ohman et al. 1983, Ohman 1990). Although foraging is a rational guess to explain the nighttime increases in biovolume near the thin layer, we were not able to collect zooplankters with the spatial and temporal precision and accuracy needed to prove that they were aggregating specifically for that purpose. The present limit of direct sampling gear for studying sub-meter-scale zooplankton structures such as these is not only an incentive to further develop non-traditional observational methods, such as acoustics and optics, but also limits our ability to study the individuals in detail.

About 13:00 h on June 20, a scattering plume was observed to extend from near the surface to $\sim 10 \mathrm{~m}$ (Fig. 4E-e). As this 'plume' of high scattering was being observed on the nearby TAPS, a long narrow $(10 \mathrm{~m}$ wide) band of crab zoea ( 0.3 to $0.4 \mathrm{~mm}$ length) were advected past the RV 'Henderson'. This band extended as far into the water column as one could see visually and on the acoustical records, and penetrated the thermocline and its associated thin-layer structures. We believe this occurrance was due to the passage of a soliton, which can lead to splitting of thin layers and temporary dispersion of zooplankton.

A deeper, more diffuse 'patch' (Fig. 4E-g) coalesced into a second thin layer at depth of about $6.75 \mathrm{~m}$ during the afternoon and evening of June 20. The layer persisted as a distinct entity beyond noon on June 21. At least 3 additional deeper but weaker thin layers also formed above the depth of the TAPS sensor during slack water during the early morning of June 21 and moved upward in the water column along with the newly formed layer. Although the size of Fig. 4E limits the resolution of detail for these layers, when one displays the data at it's full resolution it is clear that they 
persisted as a coherent, but complex vertical structure into the early evening of June 21.

During the evening of June 20, just before midnight, the acoustic scattering below the thermocline was observed to increase abruptly and then decrease almost as quickly after about $1 \mathrm{~h}$ (Fig. 4E-f). This scattering increase near the thermocline ( $\sim 5 \mathrm{~m}$ deep at the time) appeared about 16 min before scattering increased near the TAPS (then $\sim 10 \mathrm{~m}$ below the surface). A break in either the vertical distribution of the scatterers, or in its lower terminus, occurred just above the TAPS. The acoustic spectrum of the scattering from this patch revealed higher densities of both copepod-like and elongate scatterers; however, much of the increase in scattering at night was attributed to elongate scatterers between 15 and $18 \mathrm{~mm}$ in total length. We associate these sizes with adult mysids that live in or near the seabed during the day and forage in the water column at night. The brief appearance of the patch (Fig. 4E, F), along with its disappearance before sunrise, suggests that the distribution of these organisms is not horizontally homogeneous in the water column during the night. This, in turn, suggests that foraging is not homogeneous either, and the result might be the creation of horizontal heterogeneity in the thin layers during nighttime hours.

\section{Marine snow}

The percentage of the total integrated volume of marine snow (aggregates $>0.5 \mathrm{~mm}$ in diameter) in the water column in $1 \mathrm{~m}$ depth bins indicates that peaks in the quantity of marine snow were strongly correlated with the pycnocline (Fig. 4F). As the pycnocline shoaled during the second half of the study, the concentrated peaks of marine snow also shoaled. These peaks were broad and distributed over $1 \mathrm{~m}$ or more in depth. Aggregates collected by divers during this period were composed largely of unidentifiable detritus and decomposing fecal pellets interspersed with a few diatoms, especially Chaetoceros spp. (C. radicans, C. socialis, C. decipiens, C. debilis and others) and some Ditylum brightwellii, Eucampia zodiacus, Skeletonema costatum and Thalassiosira spp. Peak concentrations of marine snow occurred in close proximity to the zooplankton thin layer.

\section{Bacterial production}

The depth of maximum bacterial production was located within the pycnocline. Maximum bacterial production was correlated with both zooplankton and marine snow distribution. The maximum bacterial pro- duction ( $\mathrm{n}=4)$ averaged $24.5( \pm 3.8) \mathrm{mg} \mathrm{C} \mathrm{l}^{-1} \mathrm{~d}^{-1}$, while overall bacterial production $(\mathrm{n}=66)$ averaged 12.9 ( \pm 6.4$) \mathrm{mg} \mathrm{C} \mathrm{l}^{-1} \mathrm{~d}^{-1}$.

\section{Phytoplankton}

Thin phytoplankton layers were measured at the beginning and during the last $14 \mathrm{~h}$ of the $48 \mathrm{~h}$ sampling period (Fig. 4G). In order to be classified as a thin layer, concentrations must be at least 3 times greater than ambient concentrations (Dekshenieks et al. 2001). At 14:00 h on June 19, chlorophyll concentrations in a thin layer in the pycnocline were $>6$ times ambient. Between 13:00 and 16:00 h on June 20, chlorophyll concentrations at the pycnocline were ca. 2 times ambient. Thus, during this time, rather than being 1 pronounced thin layer (with concentrations $>3$ times ambient), there were several muted layers. These smaller muted layers were located between $\sigma_{t}$ of 21.30 and 22.0. At 20:00 h on June 20, the $21.88 \sigma_{t}$ isopleth downwelled relative to the more stratified portion of the pycnocline (Fig. 4G); this pattern is indicative of advective flow. In response, the chlorophyll concentrations increased along the $21.88 \sigma_{\mathrm{t}}$ to $>3$ times ambient; this increase persisted for a $6 \mathrm{~h}$ period. This suggests that the thin layer occurring at 20:00 h on June 20 may have been advected into the sampling area. Soon after the increase in chlorophyll concentration along the $21.88 \sigma_{\mathrm{t}}$, there was an increase in the acoustic scattering signal (cf. Fig. 4Eg). From 02:00 to 06:00 h on June 21, the phytoplankton layer measured $<1 \mathrm{~m}$. Between 06:00 and 11:00 h on June 21 , the layer measured $\sim 1 \mathrm{~m}$, with increased chlorophyll concentrations that were ca. 6 times higher than ambient concentrations. This layer was located along the $21.88 \sigma_{\mathrm{t}}$ isopycnal.

\section{Bioluminescence}

Bioluminescence profiles observed over dusk-todawn periods have long been known to exhibit maximum intensity during darkness due to circadian rhythms in some types of plankton, and/or photoinhibition of bioluminescence in others. While not all bioluminescent species are photoinhibited or have circadian rhythms governing their bioluminescent capacity, the maximum bioluminescent signal gathered by the profiling bathyphotometer, and therefore the best description of the distribution of all bioluminescent plankton present in a water column, is available during dark hours only ( 22:00 to 04:00 h in East Sound during June). Visual observation of mini-SplatCam video profiles and concurrent plankton samples re- 
vealed that the majority of bioluminescence detected by the profiling bathyphotometer was due to (1) several species of the heterotrophic dinoflagellate genus Protoperidinium, (2) several species of jellyfish, and (3) larvaceans of the genus Oikopleura. The asterisk in the bioluminescence profiles in Fig. $4 \mathrm{H}$ denotes the major layer of bioluminescence, which consists predominately of Protoperidinium spp. This layer was tracked over 8 h. From 23:00 h on June 20 until 04:00 $\mathrm{h}$ on June 21, this dinoflagellate layer shoaled as the pycnocline shoaled and was located just below the 1 $\mathrm{m}$ thick thin layer that tracked the $21.88 \sigma_{\mathrm{t}}$ isopycnal. Thinner, higher-intensity peaks located deeper in the water column were most probably single flash events caused by rare macrozooplankton with strong bioluminescence that did not appear to form thin layers.

\section{Sound-wide distribution of phytoplankton}

A thin layer of particles, detected with optical instrumentation on the 'Tyee Moon' on June 19, was spatially coherent between stations to the south of and to the north of the RV 'Henderson' (Fig. 5). Layer depth increased from south $(9.5 \mathrm{~m})$ to north $(10.75 \mathrm{~m})$ and was coincident with the base of the pycnocline $\left(21.88 \sigma_{t}\right)$ (Figs. 4G \& 5). Microscopic examination of phytoplankton samples from south and north of the RV 'Henderson' showed the layer to be dominated numerically by Chaetoceros socialis. The layer also contained enhanced levels of Thalassiosira spp., C. debilis, Pseudo-nitzschia spp. and Eucampia zodiacus (Fig. 5). Several other Chaetoceros spp. were also enhanced in the layer. The layer had concentrations of phytoplankton 3 to 4 times greater than waters just $0.5 \mathrm{~m}$ above.

Chlorophyll $a$, phytoplankton and particulate absorption

High-resolution profiles with discrete-depth water samples collected from RV 'Henderson' between 09:00 and 13:00 $\mathrm{h}$ on June 20 revealed several discrete layers of elevated beam attenuation between 21.30 and $21.88 \sigma_{\mathrm{t}}$ (Fig. 6). These profiles were collected when the pycnocline was shoaling at a low rate. Discrete samples showed that chlorophyll $a$ and phaeopigment concentrations were also associated with the same range in density (Fig. 6D). The maximum concentration of chlorophyll a $\left(14 \mu \mathrm{g} \mathrm{l}^{-1}\right)$ within the layer occurred where $\sigma_{\mathrm{t}}$ was 21.88. The chlorophyll a concentration was $\sim 3.5$ times greater than in the water above and below it. The vertical distribution of particulate absorption at $676 \mathrm{~nm}$, characteristic of phytoplankton cells, was coincident with the
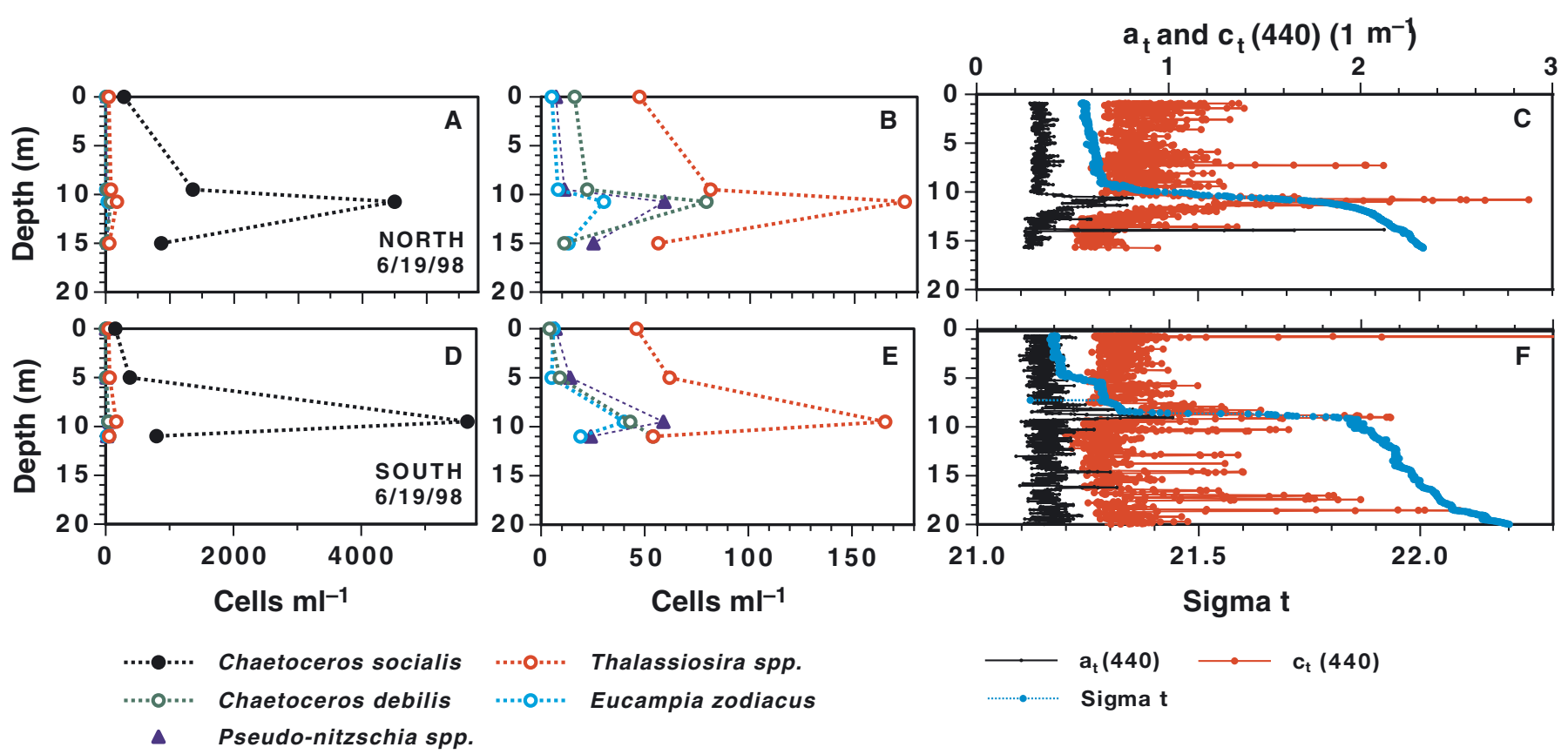

Fig. 5. Temporal, spatial and taxonomic coherence of thin phytoplankton layer on June 19, 1998. (A), (B), (D), (E) Numerical abundance of diatoms in discrete samples from surface, above, within and below optically detected layer, respectively in collectious from 'Tyee Moon'. (C), (F) Physical and inherent optical properties of water column. (A) Vertical distribution of Chaetoceros socialis north of RV 'Henderson' (48 $40.9^{\prime} \mathrm{N}^{\prime}, 122^{\circ} 53.6^{\prime}$ W). (B) Vertical distribution of other numerically dominant diatoms at same station as (A). (C) Physical and inherent optical properties of water column at same station as (A). (D) Vertical distribution of C. socialis south of RV 'Henderson' (48 $40.1^{\prime}$ N, $122^{\circ} 53.3^{\prime}$ W). (E) Vertical distribution of other numerically dominant diatoms at same station as (D). (F) Physical and inherent optical properties at same station as (D). $\mathrm{a}_{\mathrm{t}}$ : total absorption; $\mathrm{c}_{\mathrm{t}}$ : total attenuation 
chlorophyll a distribution, as was the vertical distribution of Chaetoceros socialis, the numerically dominant phytoplankton species within the layer. There were $\sim 40000$ C. socialis cells $1^{-1}$ within the layer, in contrast to $\sim 5000$ cells $1^{-1}$ above and below it (Fig. $6 \mathrm{E})$. This represents an enrichment factor of $\sim 90$ times for C. socialis within the layer. Several other diatom taxa were present within the layer at elevated concentrations relative to adjacent water, including Pseudo-nitzschia spp., C. debilis and Eucampia zodiacus, but none were as abundant as C. socialis (Fig. 6F).

\section{DISCUSSION}

Thin layers of organisms with biomass elevated at least 3 times above ambient persisted in a tidal fjord over the course of a $48 \mathrm{~h}$ study. The depth distribution of the layers was governed by local circulation patterns and episodic changes in water masses driven by regional riverine input, wind and tidal forcing. Thin layers were always associated with density gradients or step gradients in density and persisted because the turbulence present was insufficient to disrupt the layering for prolonged periods. The dominant role of
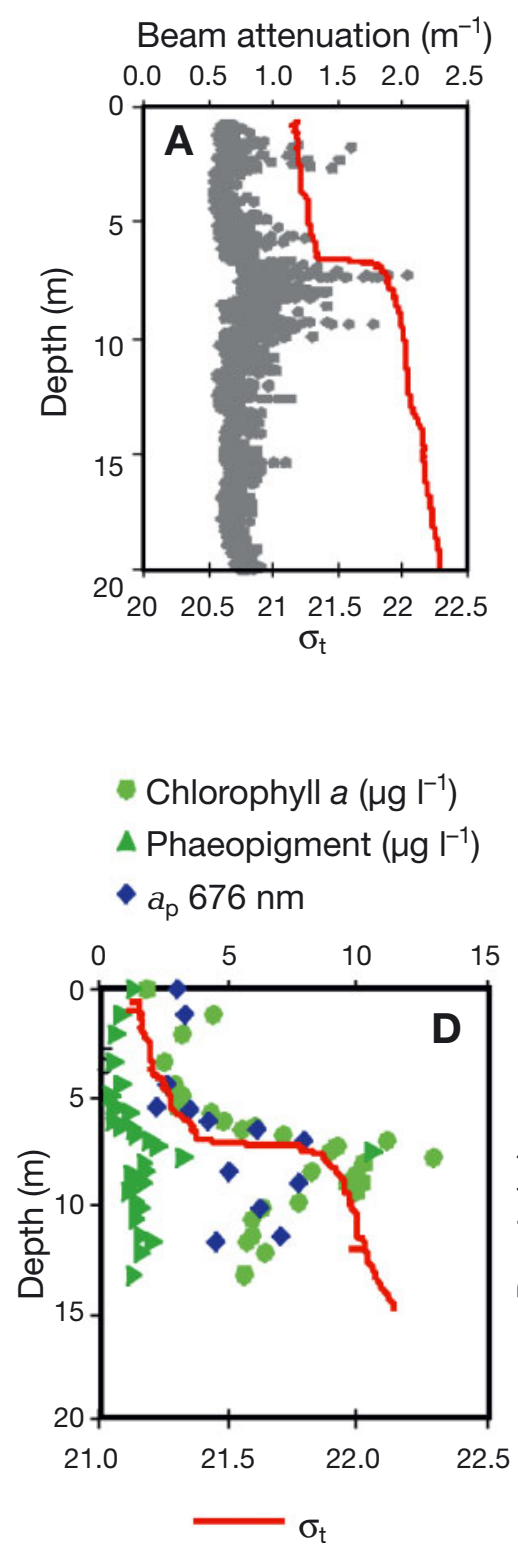

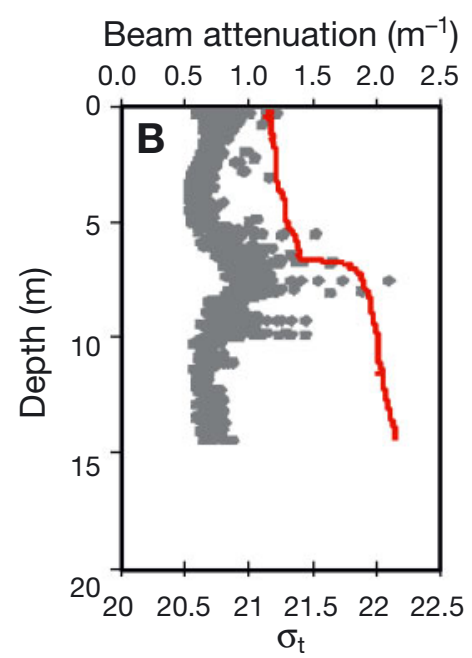

o C. socialis (cells $\mathrm{I}^{-1} \times 10^{5}$ )

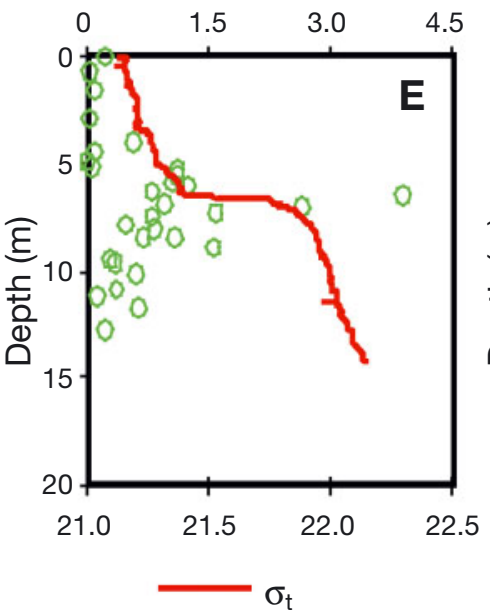

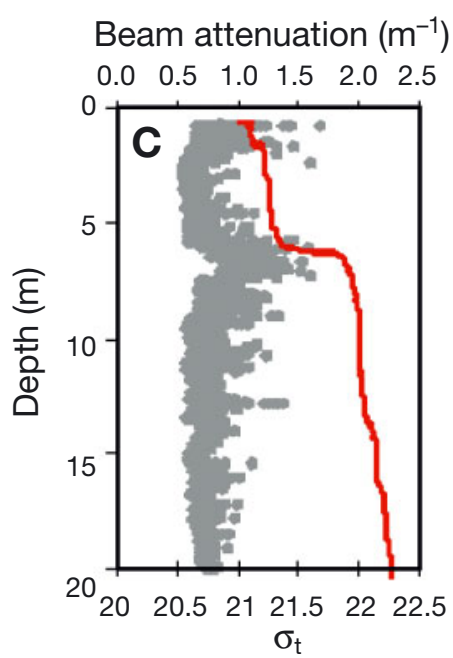

$\triangle$ Pseudo-nitzschia spp.

- Eucampia zodiacus

- Chaetoceros debilis

(cells $\mathrm{I}^{-1} \times 10^{5}$ )

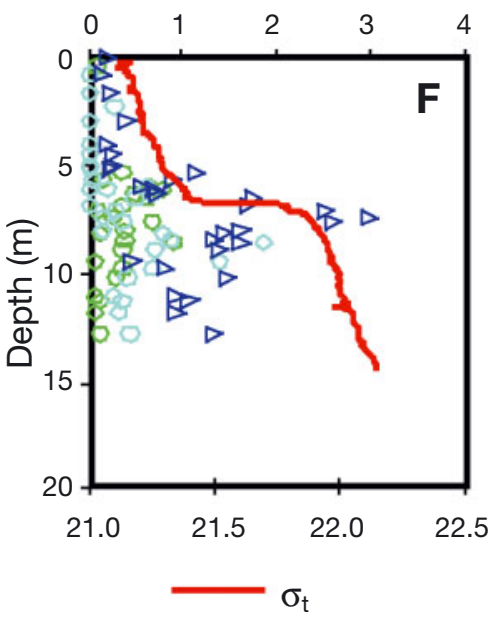

Fig. 6. High-resolution profiles collected from RV 'Henderson' on 20 June 1998. (A)-(C) Beam attenuation and $\sigma_{t}$ at (A) 09:00 h,

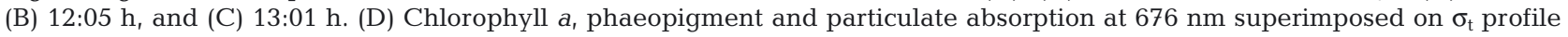
collected at 12:05 h. (E) Chaetoceros socialis abundance superimposed on $\sigma_{\mathrm{t}}$ profile collected at 12:05 h. (F) Abundance of diatoms Pseudo-nitzschia spp., Chaetoceros debilis and Eucampia zodiacus superimposed on $\sigma_{\mathrm{t}}$ profile collected at 12:05 h 
density is illustrated by the shoaling of thin layers comprised of assemblages of mesozooplankton, marine snow, bacterial production, and phytoplankton with the pycnocline over the $48 \mathrm{~h}$ period The importance of other biological and physical cues was demonstrated by the vertical separation of different types of thin layers (Fig. 7).

The greatest abundance of mesozooplankton, marine snow, and phytoplankton, and the highest bacterial productivity occurred in the pycnocline (21.30 to $21.88 \sigma_{t}$ ). At certain times, multiple thin layers of phytoplankton were located in this density interval, with the maximum in algal abundance at the base of the pycnocline $\left(21.88 \sigma_{t}\right)$. Finally, thin layers of bioluminescent dinoflagellates were located just below the peak in maximum algal abundance (Fig. 7).

\section{Distributions within the pycnocline}

\section{Mesozooplankton}

Mesozooplankton distribution had 2 characteristic features: (1) increased numbers of organisms in the water column at night due to migratory behavior, (2) persistent thin-layer structures. We suggest that a biological mechanism involving a spatially patchy migratory behavior brings mysids to the pycnocline $\left(21.30\right.$ to $\left.21.88 \sigma_{t}\right)$, producing the thin layer of acoustic scattering. These thin layers of mesozooplankton (Fig. 4E) were dispersed temporarily when current shear and turbulence were enhanced due to the passage of solitons. These dispersal events, however, were brief and the thin layer of mesozooplankton rapidly reformed-mesozooplankton swimming speeds appear to be high enough to overcome the average vertical mixing intensity in the water column (due to low tur-

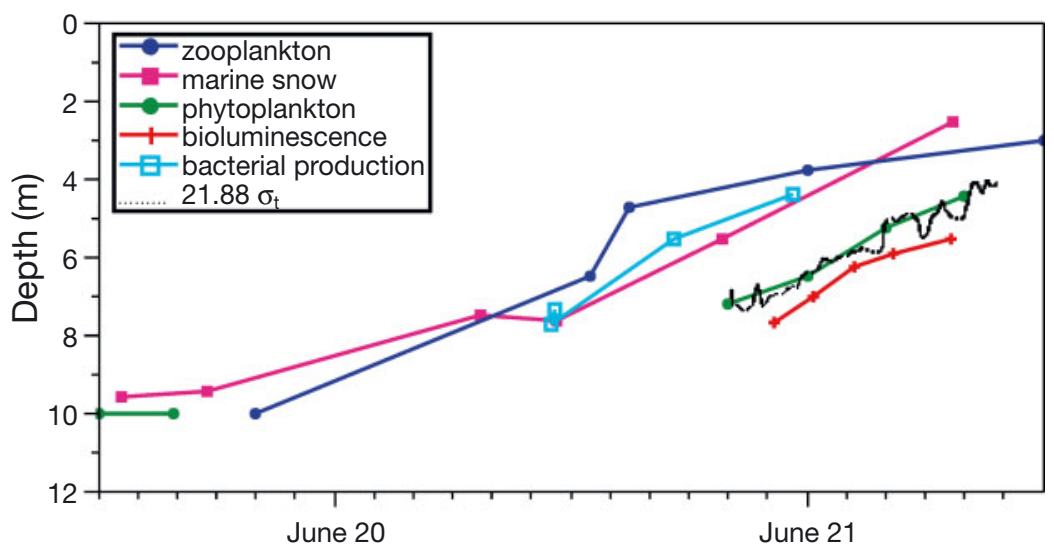

Fig. 7. Depth of maximum concentration of total small mesozooplankton biovolume, marine snow, phytoplankton, bioluminescence, and bacterial production as a function of time, and of $21.88 \sigma_{\mathrm{t}}$ as a function of time bulence $\left[\varepsilon<10^{-8} \mathrm{~m}^{2} \mathrm{~s}^{-3}\right]$ and small eddy sizes $[l$ on $\mathrm{cm}$ scales], average turbulent-velocity scales computed as $u_{*}=[\varepsilon l]^{1 / 3}$ are on the order of $\mathrm{mm} \mathrm{s}^{-1}$ ). Mesozooplankton layers are temporarily diffused only when turbulence levels exceed the speed of vertical migration.

Marine snow

The broad peaks of marine snow were similar to distribution patterns of marine snow at density discontinuities reported for other coastal areas (MacIntyre et al. 1995). The concentrations of marine snow observed in 1998 did not reach the very high abundances and narrowly defined depth range of a $50 \mathrm{~cm}$ thick thin layer of mucus-rich diatom marine snow observed in East Sound in 1996 (Alldredge et al. 2002). The largely detrital composition of the aggregates observed in 1998 suggests they had relatively high porosity (MacIntyre et al. 1995). Accumulation of porous marine snow could result from temporary deceleration of aggregates sinking from above, increased particle aggregation in areas of fine-grained turbulence, and/or intrusions of particles (MacIntyre et al. 1995).

\section{Bacterial production}

The maximum bacterial production rate was closely associated with zooplankton and marine snow distributions. The high bacterial production rates may have been the result of increased dissolved organic matter (DOM) production in this layer, where concentrations of marine snow and zooplankton were highest. Solubilization of marine snow by bacterial ectoenzymes (Smith et al. 1992) and the feeding activities of zooplankton (Lampert 1978) and heterotrophic protists

(Strom et al. 1997) are known mechanisms for DOM production and can stimulate bacterial growth. The maximum bacterial abundance (data not shown) did not correspond with the maximum bacterial productivity. Bacterial loss rates may have been higher elsewhere within the pycnocline and are consistent with the high abundance there of heterotrophic protists (data not shown).

\section{Phytoplankton}

We observed a thin phytoplankton layer dominated by the colonial diatom Chaetoceros socialis, associated with 
the $21.88 \sigma_{\mathrm{t}}$. This thin layer persisted from the afternoon of June 20 to the late morning of June 21. This finding is consistent with previous results showing a strong statistical relationship between thin phytoplankton layers and physical structure. In 1996, over $71 \%$ of all thin phytoplankton layers detected were located at the base of the pycnocline (Dekshenieks et al. 2001).

Thin layers of phytoplankton are spatially and temporally coherent, but they may have different taxonomic properties. The thin layer along the $21.88 \sigma_{t}$ isopycnal documented in this study was contiguous over the 3 stations sampled in the north part of the Sound, and persisted throughout the $48 \mathrm{~h}$ period. It was composed of an enhanced concentration of phytoplankton taxa that were also present at lower concentrations throughout the water column. It should be noted that thin layers of phytoplankton composed of taxa whose distribution is restricted to one layer have been observed in East Sound (Rines et al. 2002). This suggests that layer composition is highly dependent on seed populations.

\section{Distributions below the pycnocline}

\section{Bioluminescence}

The thin layer of bioluminescence observed was spatially distinct from the shallower thin layers characterized by mesozooplankton, marine snow, and high bacterial production, as well as phytoplankton, but was consistently found immediately below the thin phytoplankton layer that formed in the latter portion of our study. In contrast to the other layers, the bioluminescent organisms could not be tracked with our instruments during daylight because the layer was composed predominantly of the heterotrophic dinoflagellate Protoperidinium leonis, whose luminescence is photoinhibited (Buskey et al. 1992, 1994, Li et al. 1996). This is the first report of heterotrophic dinoflagellates dominating the overall bioluminescence signal for a shallow coastal area, although this has been widely reported in oceanic studies (Lapota et al. 1989, Buskey 1995, Swift et al. 1995).

Although diatoms are the primary food source of Protoperidinium spp. (e.g. Buskey et al. 1994, Jeong \& Latz 1994), P. leonis were found below the thin layer of phytoplankton (where Chaetoceros socialis was less abundant), and may have been avoiding interference with its delicate pallial-feeding process by feeding in the more sparsely populated water below the thin layer. Because this layer harbored the most intense bioluminescence in the water column $\left(10^{13}\right.$ photons $\mathrm{l}^{-1}$ ), we can reliably infer that the bioluminescent organisms had not been nutritionally stressed, at least in the preceding few days, because Protoperidinium spp. generally respond to nutritional stress with reduced bioluminescence levels (Buskey et al. 1992, 1994). Widder et al. (1999) also reported bioluminescent thin layers that were correlated with density discontinuities (in an oceanic environment), but those layers were composed of vertically migrating copepods, which have more control over their distribution than dinoflagellates. Based on these 2 studies, we conclude that the depth distributions of bioluminescent thin layers can be controlled by the physical structure of the water column as well as by organism behavior, depending on the species composition of the layer.

This study, as well as previous ones (Dekshenieks et al. 2001, Alldredge et al. 2002, Rines et al. 2002), has shown that thin layers are associated with highly stratified regions of the water column where the Richardson number $\mathrm{Ri}$ is $>0.25$. Previous results have shown that $95 \%$ of a thin phytoplankton layers were located in regions of low to moderate shear (0 to $0.05 \mathrm{~s}^{-1}$; Dekshenieks et al. 2001). Similarly, our results for 1998 show that thin layers of phytoplankton were not present in regions of high shear. In fact, the most intense layers developed following periods of high shear (Fig. 4A,G), perhaps indicating the advection of a new water mass.

Our measurements of turbulence verify the interpretation of the Richardson numbers. Rates of dissipation of turbulent kinetic energy $(\varepsilon)$ were low-to-moderate $\left(\varepsilon<10^{-8} \mathrm{~m}^{2} \mathrm{~s}^{-3}\right)$ where thin layers were found, except when solitons were present. Solitons can lead to splitting of thin layers and temporary dispersion of zooplankton ( 12:30 to 14:00 h on June 20), but since they are infrequent in this system the overall effect on organism distributions is minor. Recent observations in open waters of stratified lakes and estuaries have shown that both mixing efficiencies and buoyancy fluxes are low, except during times of strong wind or tidal forcing (MacIntyre et al. 1999, MacIntyre \& Jellison 2001, Saggio \& Imberger 2001, Etemad-Shahidi \& Imberger 2002). Thus, the persistence of thin layers in open waters may depend on the frequency and occurrence of mixing events caused by strong wind or tidal forcing. On the other hand, mixing events in nearshore waters are likely to generate intrusions with elevated nutrient concentrations (J. G. MacIntyre unpubl. data). These mixing events could contribute to the eventual formation of thin layers.

To discern which physical and biological processes contribute to the formation, maintenance and dissipation of thin layers, it is necessary to consider physical processes across a range of scales (from large-scale changes in hydrography to small-scale mixing processes) and biological processes for each distinct 
species within the thin layer. Large-scale physical processes, such as a change in water-mass type modulating the position of the pycnocline and advection, will affect the general distribution of the planktonic community. On smaller physical scales, layers are observed in stable regions of the water column, where $\mathrm{Ri}$ is $>0.25$ and where turbulence is anisotropic and generally insufficient to cause vertical transport. Superimposed on the physical processes structuring the distribution of the planktonic communities, are species-specific behaviors, growth rates, grazing rates and mortality rates. The relative rates of these biological species-specific processes, in combination with physical processes, ultimately determine the spatial distribution and temporal occurrence of thin layers.

\section{Conclusions}

Significant advances in oceanographic instrumentation have permitted high-resolution observations of thin layers in the marine environment. The formation, distribution and persistence of these layers depend on a variety of biological and/or physical processes. While they are temporally persistent, layer composition can vary with depth. Consequently, the combination of biological and/or physical processes structuring the layers is unique to each layer 'type'. Therefore, it is critical to address the study of thin layers using an integrated multidisciplinary approach in combination with measurements and sampling at the spatial and temporal scales appropriate to resolve the layers. Observations of thin layers of biological organisms are not limited to the East Sound. Thin layers are a widespread phenomenon, observed wherever conditions for their formation are appropriate. These areas include fjords (Bjornsen \& Nielsen 1991, Johnson et al. 1995, Dekshenieks et al. 2001, this study), river mouths (Gentien et al. 1995), the continental shelf (Cowles \& Desidero 1993, Cowles et al. 1993), and shelf basins (Widder 1997).

Organisms within thin layers are several orders of magnitude more abundant than in the water immediately above or below the layers. On the basis of abundance alone, layer organisms have the potential to dominate the trophic dynamics, as well as the optical and acoustical signatures of the water column. Our study of East Sound documents the existence of multiple thin layers of zooplankton, marine snow, bacterial production, phytoplankton and bioluminescence in a relatively shallow, although physically complex, water column. The vertical distribution of plankton in layers has potentially significant ecological consequences, including increased probability of predator-prey encounter (e.g. Lasker 1975) and enhanced water-column productivity (e.g. Rovinsky et al. 1997, Brentnall et al. 2003). In addition, the layers provide a 3-dimensional biological structure in the water column, a phenomenon that may partially explain the 'paradox of the plankton' (Hutchinson 1961), in which high species diversity occurs in small, seemingly homogeneous parcels of water. In effect, thin layers produce microenvironments of physical, chemical and biological parameters. The persistence of these microenvironments and their unique community structure over time scales that are as long, or longer, than the generation times of many plankton species, is likely to preserve and maintain species diversity by spatial partitioning of the pelagic environment. The detailed function and role of thin layers in facilitating high plankton species diversity and their impact on the evolution and persistence of plankton communities remain to be investigated.

Acknowledgements. We thank Paul Aguilar, Jennifer Bivens, The Beilfuss family, Mike Costello, Russ Desidero, Rob and Sara Endicott, Kevin Flynn, Steve Haddock, Cyril Johnson, James King, Malcolm MacFarland, Hazel Mahon, Jeff Merrell, Nathan Potter, Rosario Resort, Jeremy Roswell, John Ryan, William Shaw, Rudy Stuber, Andrea VanderWoude, Chris Wingard, Carol Wyatt-Evens and the Youngren family. Special thanks to Eric Boget (captain of RV 'Henderson'). We also thank 3 anonymous reviewers who provided constructive comments on the manuscript. This research was supported by the Office of Naval Research Biological \& Chemical Oceanography awards N00014-95-0225 (P.L.D.), N00014-96-1-0069 (A.A., S.M.), N00014-96-0247 (J.E.B.R., P.L.D.), N00014-96-10291 (D.J.G.), N00014-97-1-0424 (J.C.), N00014-98-C-0025 (D.V.H.), N00014-98-1-0847 (D.C.S.), N00014-00-D-0122 (D.V.H.); by the Office of Naval Research Physical Oceanography awards N00014-99-1-0293 (M.M., P.L.D., T.R.O.), N00014-01-1-0206 (M.M., P.L.D., T.R.O.); by the Office of Naval Research Environmental Optics awards N00014-98-10252 (T.J.C.); and by the National Science Foundation awards DEB-97-26932 (S.M.), DEB01-08572 (S.M.), OCE-99-06924 (S.M.). We are grateful for this support.

\section{LITERATURE CITED}

Alldredge AL, Cowles TJ, MacIntyre S, Rines JEB and 6 others (2002) Occurrence and mechanism of formation of a dramatic thin layer of marine snow in a shallow Pacific fjord. Mar Ecol Prog Ser 233:1-12

Anderson GC (1969) Subsurface chlorophyll maximum in the northeast Pacific Ocean. Limnol Oceanogr 14:386-391

Barnard AH, Pegau WS, Zaneveld JRV (1998) Global relationships in the inherent optical properties of the oceans. J Geophys Res 103:955-968

Bjornsen PK, Nielsen TK (1991) Decimeter scale heterogeneity in the plankton during a pycnocline bloom of Gyrodinium aureolum. Mar Ecol Prog Ser 73:263-267

Brentnall SJ, Richards KJ, Brindley J, Murphy E (2003) Plankton patchiness and its effect on larger-scale productivity. J Plankton Res 25:121-140

Bricaud A, Stramski D (1990) Spectral absorption coefficients of living phytoplankton and nonalgal biogenous matter: 
a comparison between the Peru upwelling area and Sargasso Sea. Limnol Oceanogr 35:562-582

Buskey EJ (1995) Bioluminescence and growth rates of heterotrophic dinoflagellates on varying algal diets: implications for studies of bioluminescence in the Arabic Sea. In: Thompson MF, Tirmizi NM (eds) The Arabian Sea: living marine resources and the environment. AA Balkema, Rotterdam, p 149-160

Buskey EJ, Strom S, Coulter CJ (1992) Bioluminescence of heterotrophic dinoflagellates from Texas coastal waters. J Exp Mar Biol Ecol 159:37-49

Buskey EJ, Coulter CJ, Brown SL (1994) Feeding, growth, and bioluminescence of the heterotrophic dinoflagellate Protoperidinium huberi. Mar Biol 121:373-380

Cassie RM (1963) Multivariate analysis in the interpretation of numerical plankton data. NZ J Sci 6:36-59

Cowles TJ, Desiderio RA (1993) Resolution of biological microstructure through in situ fluorescence emission spectra: an oceanographic application using optical fibers. Oceanography 6:105-111

Cowles TJ, Desiderio RA, Neuer S (1993) In situ characterization of phytoplankton from vertical profiles of fluorescence emission spectra. Mar Biol 115:217-222

Cowles TJ, Desiderio RA, Carr ME (1998) Small-scale planktonic structure: persistence and trophic consequences. Oceanography 11:4-9

Cushing DH (1962) Patchiness. Rapp P-V Cons Int Explor Mer 153:152-164

Dekshenieks MM, Donaghay PL, Sullivan JM, Rines JEB, Osborn TR, Twardowski MS (2001) Temporal and spatial occurrence of thin phytoplankton layers in relation to physical processes. Mar Ecol Prog Ser 223:61-71

Donaghay PL, Rines HM, Sieburth J McN (1992) Simultaneous sampling of fine scale biological, chemical and physical structure in stratified waters. Ergeb Limnol 36:97-108

Etemad-Shahidi A, Imberger J (2001) Anatomy of turbulence in thermally stratified lakes. Limnol Oceanogr 46: $1158-1170$

Etemad-Shahidi A, Imberger J (2002) Anatomy of turbulence in a narrow and strongly stratified estuary. J Geophys Res C Oceans 107 10.1029/2001JC000977

Gentien P, Luven M, Lehaitre M, Duvent JL (1995) In-situ depth profiling of particle sizes. Deep-Sea Res 42: $1297-1312$

Gifford DJ, Caron DA (2000) Sampling, preservation, enumeration and biomass of marine protozooplankton. In: Harris $\mathrm{RP}$ et al. (eds) Zooplankton methodology manual. Academic Press, London, p 193-221

Griffin DA, LeBlond PH (1990) Estuary-ocean exchange controlled by spring-neap tidal mixing. Estuar Coast Shelf Sci 30:275-297

Hanson AK Jr, Donaghay PL (1998) Micro- to fine-scale chemical gradients and layers in stratified coastal waters. Oceanography 11:10-17

Haurey LR, McGowan JR, Wiebe PH (1978) Patterns and processes in the time-space scales of plankton distributions. In: Steele JH (ed) Spatial pattern in plankton communities. Plenum Press, New York, p 277-327

Hickey BM, Thomson RE, Yih H, LeBlond PH (1991) Velocity and temperature fluctuations in a buoyancy-driven current off Vancouver Island. J Geophys Res C Ocean 96: 10507-10538

Holliday DV (1977) Extracting bio-physical information from the acoustic signatures of marine organisms. In: Anderson NR, Zahuranec BJ (eds) Ocean sound scattering prediction. Plenum Press, New York, p 619-624

Holliday DV, Pieper RE, Greenlaw CF, Dawson JK (1998)
Acoustical sensing of small-scale vertical structures. Oceanography 11:18-23

Holliday DV, Donaghay PL, Greenlaw CF, McGehee DE, McManus MA, Sullivan JM, Miksis JL (2003) Advances in defining fine- and micro-scaale pattern in plankton. Aquat Living Resour 16(3):131-136

Hutchinson GE (1961) The paradox of the plankton. Am Nat 95:137-145

Itsweire EC, Osborn TR, Stanton TP (1989) Horizontal distribution and characteristics of shear layers in the seasonal thermocline. J Phys Oceanogr 19:301-320

Itsweire EC, Koseff JR, Briggs D, Ferziger JH (1993) Turbulence in stratified-shear flows: implications for interpreting shear-induced mixing in the ocean. J Phys Oceanogr 23:1508-1522

Ivey G, Imberger J (1991) On the nature of turbulence in a stratified fluid. Part 1: The efficiency of mixing. J Phys Oceanogr 21:650-658

Jeong HJ, Latz MI (1994) Growth and grazing rates of the heterotrophic dinoflagellates Protoperidinium spp. on red tide dinoflagellates. Mar Ecol Prog Ser 106:173-185

Johnson PJ, Donaghay PL, Small EB, Sieburth J McN (1995) Ultrastructure and ecology of Perispira ovum (Ciliophora: Litostomatea): an aerobic planktonic ciliate that sequesters the chloroplasts, mitochondria and paramylon of Euglena proxima in a micro-oxic habitat. J Eukaryot Microbiol 422: 323-335

Kirchman D, K'Nees E, Hodson R (1985) Leucine incorporation and its potential as a measure of protein synthesis by bacteria in natural aquatic systems. Appl Environ Microbiol 49:599-607

Kishino M, Takahashi M, Okami N, Ichimura I (1985) Estimation of the spectral absorption ocoefficients of phytoplankton in the sea. Bull Mar Sci 37:634-642

Kringel K, Holliday DV, Jumars PA (in press) A shallow scattering layer: high-resolution acoustic analysis of nocturnal vertical migration from the seabed. Limnol Oceanogr

Lampert W (1978) Release of dissolved organic carbon by grazing zooplankton. Limnol Oceanogr 23:831-834

Lapota D, Geiger ML, Stiffey AV, Rosenberger DE, Young DK (1989) Correlations of planktonic bioluminescence with other oceanographic parameters from a Norwegian fjord. Mar Ecol Prog Ser 55:217-228

Lasker R (1975) Field criteria for the survival of anchovy larvae: the relation between inshore chlorophyll maximum layers and successful first feeding. Fish Bull 73:453-462

Li Y, Swift E, Buskey EJ (1996) Photoinhibition of mechanically stimulable bioluminescence in the heterotrophic dinoflagellate Protoperidinium depressum (Pyrrophyta). J Phycol 32:974-982

MacIntyre S (1998) Turbulent mixing and resource supply to phytoplankton. In: Imberger J (ed) Physical processes in lakes and oceans. American Geophysical Union, Washington, DC, p 539-567

MacIntyre S, Jellison R (2001) Nutrient fluxes from upwelling and enhanced turbulence at the top of the pycnocline in Mono Lake, California. Hydrobiologia 466:13-29

MacIntyre S, Alldredge AL, Gotschalk CC (1995) Accumulation of marine snow at density discontinuities in the water column. Limnol Oceanogr 40:449-468

MacIntyre S, Flynn KM, Jellison R, Romero JR (1999) Boundary mixing and nutrient flux in Mono Lake, CA. Limnol Oceanogr 44:512-529

Mackas DL, Boyd CM (1979) Spectral analysis of zooplankton spatial heterogeneity. Science 204:62-64

McGehee DE, O'Driscoll RL, Martin-Traykovski LV (1998) Effects of orientation on acoustic scattering from Antarctic 
krill at $120 \mathrm{kHz}$. Deep-Sea Res Part II Oceanogr Res Pap 45:1273-1294

Mitchell BG, Kiefer DA (1988) Chlorophyll a specific absorption and fluorescence excitation spectra for light-limited phytoplankton. Deep-Sea Res 35:639-663

Mullin MM (1993) Webs and scales: physical and biological processes in marine fish recruitment. Washington Sea Grant Program, Seattle, WA

Ohman MD (1990) The demographic benefits of diel vertical migration by zooplankton. Ecol Monogr 60:257-281

Ohman MD, Frost BW, Cohen EB (1983) Reverse diel vertical migration: an escape from invertebrate predators. Science 220:1404-1407

Parsons TR, Maita Y, Lalli CM (1984) A manual of chemical and biological methods for seawater analysis. Pergamon Press, Oxford

Pieper RE, Holliday DV (1984) Acoustic measurements of zooplankton distributions in the sea. J Cons Int Explor Mer 41:226-238

Redfield AC (1950) Note on the circulation of a deep estuary: the Juan de Fuca-Georgia Straits. In: Proceedings of the Colloquium on Flushing of Estuaries. Woods Hole Oceanographic Institution Woods Hole, MA, p 175-177

Rines JEB, Donaghay PL, Dekshenieks MM, Sullivan JM, Twardowski MS (2002) Thin layers and camouflage: hidden Pseudo-nitzschia populations in a fjord in the San Juan Islands, Washington, USA. Mar Ecol Prog Ser 225: 123-137

Rovinsky AW, Adiwidjaja H, Yakhnin VZ, Menzinger M (1997) Patchiness and enhancement of productivity in plankton ecosystems due to differential advection of predator and prey. Oikos 78:101-106

Saggio A, Imberger J (2001) Mixing in turbulent fluxes in the metalimnion of a stratified lake. Limnol Oceanogr 46: 392-409

Simon M, Azam F (1989) Protein content and protein synthesis rates of planktonic marine bacteria. Mar Ecol Prog Ser 51:201-213

Smith DC, Azam F (1992) A simple, economical method for

Editorial responsibility: Barry and Evelyn Sherr (Contributing Editors), Corvallis, Oregon, USA measuring bacterial protein synthesis rates in seawater using 3H-leucine. Mar Microb Food Webs 6:107-114

Smith DC, Simon M, Alldredge AL, Azam F (1992) Intense hydrolytic enzyme activity on marine aggregates and implications for rapid particle dissolution. Nature 359: 139-142

Strom SL, Benner R, Ziegler R, Dagg MJ (1997) Planktonic grazers are a potentially important source of marine dissolved organic carbon. Limnol Oceanogr 42:1364-1374

Swift E, Sullivan JM, Batchelder HP, Vankeuren J, Vaillancourt RD, Bidigare RR (1995) Bioluminescent organisms and bioluminescence measurements in the north Atlantic ocean near latitude 59.5 degrees N, longitude 21 degrees W. J Geophys Res 100:6527-6547

Thomson RE (1981) Oceanography of the British Columbia coast. Can Spec Publ Fish Aquat Sci Bull 56, Fisheries and Oceans Canada, Ottawa

Turner JS (1973) Buoyancy effects in fluids. University Press, Cambridge, UK

Twardowski MS, Sullivan JM, Donaghay PL, Zaneveld JRV (1999) Microscale quantification of the absorption by dissolved and particulate material in coastal waters with an ac-9. J Atmos Oceanic Technol 16:691-707

Widder EA (1997) Bioluminescence (US Navy's Research). Sea Technol 38:33-39

Widder EA, Bernstein S, Bracher D, Case JF, Reisenbichler KR, Torres JJ, Robison BH (1989) Bioluminescence in the Monterey Submarine Canyon: image analysis of video recordings from a midwater submersible. Mar Biol 100: $541-551$

Widder EA, Greene CH, Youngbluth MJ (1992) Bioluminescence of sound-scattering layers in the Gulf of Maine. J Plankton Res 14:1607-1624

Widder EA, Johnsen S, Bernstein SA, Case JF, Neilson DJ (1999) Thin layers of bioluminescent copepods found at density discontinuities in the water column. Mar Biol 134: 429-437

Wiebe PH, Holland WR (1968) Plankton patchiness: effects on repeated net tows. Limnol Oceanogr 13:315-321

Submitted: June 14, 2002; Accepted: April 29, 2003

Proofs received from author(s): September 8, 2003 